\title{
On depictive secondary predicates in Laz
}

\author{
SILVIA KUTSCHER AND N. SEVIM GENÇ
}

\subsection{Introduction}

This chapter deals with morphosyntactic, semantic, and prosodic characteristics of depictive secondary predication in Laz. We show that Laz adjunct expressions generally cannot be divided into depictive and adverbial constructions on the basis of their morphosyntactic properties. We also deal with some prosodic characteristics of adjuncts expressing manner and state, and discuss to what extent depictive expressions may be delimited from manner adverbials on the grounds of intonational patterns. Concerning the semantic interpretation of adjuncts in Laz, we argue that they are vague with respect to participant- or event-oriented readings. Laz clause-level adjuncts thus are general adjunct constructions in the terminology proposed in the introduction to this volume. An interesting exception to this generalization are distributive numeral expressions, which can be argued to be a genuine depictive construction.

A sister language of Georgian, spoken on the south-eastern coast of the Black Sea, Laz is the only member of the South Caucasian family which is spoken primarily outside Georgia. The vast majority of its speakers live in Turkey and are bilingual. An increasing number of young Laz, however, are fluent only in Turkish. In addition, native speakers of Laz restrict using their mother tongue to private communications amongst friends and family members.

The variety of Laz discussed here is the one spoken in the city of Ardeşen and the villages of the Ardeşen region. Although this dialect (Ardeşen-Laz) differs from other Laz varieties with respect to the case-marking system (see Kutscher 2001: ch. 5), it is similar to the other dialects in that no variant of Laz exhibits

The authors would like to thank Eva Schultze-Berndt, Nikolaus Himmelmann, and Katrin Lehmann for numerous comments on previous versions of this chapter, and Britt Temme for brushing up our English. We also are grateful to the patience and helpfulness of the Laz speakers in the region of Ardeşen and in Germany, who have supported our work for several years now. 
NP internal agreement or an adverbialis case, in contrast to the Georgian varieties discussed by Boeder (Ch. 6 , this volume).

The data presented in this chapter consist of utterances taken from a corpus of spoken texts recorded on location in Turkey. Some texts from this corpus have been published in Wodarg (1995) and Kutscher and Genç (1998). Examples from these publications are marked with $W$ (for Wodarg) and K/G (for Kutscher and Genc) followed by an abbreviated title of the source text and the reference number of the intonation unit (e.g. K/G murunzxi o03). Other examples are from our research on positional verbs elicited with stimuli of the Language and Cognition Group of the Max Planck Institute for Psycholinguistics in Nijmegen. These are marked 'Posit'. Examples not marked for their source have been elicited for the purposes of this article.

The structure of the chapter is as follows. Section 7.2 gives a short overview of Laz basic clause structure. Section 7.3 focuses on how NP-internal modifiers can be delimited from adjuncts. Section 7.4 concerns participantoriented and event-oriented manner expressions, and gives an overview on their segmental and distributional characteristics (7.4.1) followed by a few remarks on prosodic communalities and differences (7.4.2). Section 5 deals with participant-oriented and event-oriented uses of adjuncts in instrumental case (7.5.1), motative case (7.5.2), and locational nominals (7.5.3). Section 7.6 argues that distributive numerals are expressed by a genuine depictive construction in Laz. Section 7.7 deals with expressions of role and life stage, which in Laz are biclausal in nature. Section 7.8 concludes.

\subsection{Morphosyntactic essentials}

Laz is basically an SOV language, exhibiting the categories case and number in nominal expressions and a rich inventory of verbal categories with up to ten different morphological slots to be filled in the predicate (see Kutscher 2001: ch. 1). Predicates in Laz are head-marking-i.e. depending on the valence of the verb, verbal inflection is mono- or polypersonal.

With polypersonal verbs the finite verb inflects for both actor and undergoer as in (1).

(1) cem $_{\mathfrak{c} a m^{1}}$

hit:[2 $>1$ 1] sG.PRs

'You beat me.'

${ }^{1}$ Examples are written in the Lazoglu/Feurstein orthography introduced to the Laz community in Turkey in 1984. It deviates from the Caucasianists' transcription in the following graphemes $(<\mathrm{Laz}=$ Caucasianist $>):\langle\mathrm{q}=\breve{\mathrm{c}}\rangle,\langle\mathrm{c}=\mathrm{j}\rangle,\langle\grave{\mathrm{k}}=\mathrm{k}\rangle,\langle\mathrm{p}=\dot{\mathrm{p}}\rangle,\langle\hat{\mathrm{s}}=\breve{\mathrm{s}}\rangle,\langle\mathrm{t}=\mathrm{t}\rangle,\langle 3=\mathrm{c}\rangle,\langle\breve{\mathrm{z}}=\mathrm{c}\rangle$. 
Laz is an active language (Klimov 1974), i.e. monopersonal verbs subdivide into two classes, depending on whether the verb takes a controlling or non-controlling single core argument. Controlling single core arguments are marked as actor on the predicate, cf. the first person marker $b$ - in (2a). Non-controlling single core arguments are marked as undergoer, cf. the first person marker $m$ - in (2b). This is indicated by an arrow $(>)$ in the gloss.

\section{(2) a. bulur}

go:1SG.PRS

'I go.'

b. maçinden

sneeze:>1SG.PRS

'I sneeze.'

Note that information on person and number in Laz predicates is not marked by a single prefix but rather results from the interaction of prefixes and suffixes. These are portmanteau forms coding tense/aspect $/ \mathrm{mood}$ simultaneously (see Mattissen 1995). ${ }^{2}$

Argument NPs are always non-obligatory and often are omitted in discourse. If present, all argument NPs in Ardeşen-Laz are unmarked for case, as opposed to other Laz dialects. This holds for the actors of polypersonal predicates $(3 a, b)$, primary and secondary objects $(3 b)$, and for the single core argument of monopersonal inactive predicates $(3 \mathrm{c})$.

\section{(3) a. baba pencere kosuy}

father window clean:[3>3]sG.PRS

'Father wipes the window.'

\section{b. nana baba bere meçay}

mother father child give:[3>3]sG.PRS

'Mother gives the child to Father.'

c. biçi aş̌kurinen

boy be_afraid:>3SG.PRS

'The boy is afraid.'

${ }^{2}$ Person-marking in the glosses includes information on the macro-roles actor and undergoer. Undergoers are marked with a preceding angled bracket, $>$. In polypersonal predicates this bracket is to be read as 'acts on'. In monopersonal-inactive predicates, it marks the single core argument as a non-controlling argument. The single core argument of monopersonal active predicates is an actor and has no special marking. 
Adjuncts, e.g. goals (4a) or instruments (4b) take oblique case-marking.

(4)
a. receǩkuleșa
eşkjaftaten (...)
receǩule-şa
eşka-ftaten
'place name'-мoT up-go:IPL.FUT.PFV
'We went up to recekule.' (K/G gecekule 005)

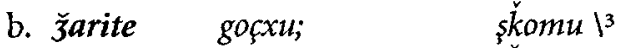
3̌ari-te goçxu škomu

water-INS clean:3SG.PST.PFV eat:3SG.PST.PFV

'He cleaned it with water and ate it.' (K/G proyoni 031)

Expressions of location (5a) or time (5b), however, are always unmarked for case.
(5) a. Trabzoni ya (o.3) xolo teyyare kocepxedi
Trabzoni ya xolo teyyare ko-ce-pxedi
Trabzon QUOT again plane EMPH-down-sit:1sG.PST.PFV
'He said: "In Trabzon $I$ sat down in an airplane once again".' (K/G Ferat dayi $1002 / 3$ )

b. a mapxa ndya; (o.1) xvala pucepe

a mapxa ndya xvala puci-pe

keşǩkebuçvi

k-eşkebuçvi

EMPH-up: lead:[1>3]sG.PST.PFV

'One sunny day I brought the cows up alone.' (W Kuhtext 004)

Having set out the major characteristics of Laz clause structure, in the following sections we will turn to the nature of participant-oriented adjunct constructions beginning with delimiting unmarked adjuncts from NP-internal modifiers.

\subsection{Participant-oriented adjuncts vs. NP-internal modifiers}

In contrast to Georgian (see Boeder, Ch. 6, this volume), Laz NPs only inflect on the last element of the phrase and do not exhibit NP-internal agreement,

${ }^{3}$ In transcripts of audio data intonational units are delimited as follows: $1=$ final intonation, i.e. pitch drops to the base line; $;=$ medial intonation, i.e. pitch ends in mid-range either level or slightly falling; $/=$ progredient intonation, i.e. final pitch is clearly rising. A number in brackets, e.g. (o.1), indicates the length of a pause in seconds. 
as (6) illustrates (see Kutscher 2001: ch. 2 for details).

(6)

$\begin{array}{lll}\text { (...) pasiari lemşite } & \text { kelebuçi / } \\ \text { pasiari } & \text { lemşi-te } & \text { ko-elebuç̧i } \\ \text { rusty } & \text { needle-INS } & \text { EMPH-sew:[1>3] SG.PST.PFV }\end{array}$

'I sew it together with a rusty needle.' (K/G korme o11)

In (6) the instrument-NP pasiari lemsite 'with a rusty needle' is case marked only on the semantic nucleus (lemşi 'needle') of the NP, whereas the attribute pasiari 'rusty' is a bare adjective stem. The last lexical element of an NP can either be the semantic nucleus (as in (6)) or a possessive pronoun (cf. (7)).

$\begin{array}{llll}\text { pasiari lemşi } & \text { škimi-te } & \text { kelebuçi } \\ \text { pasiari lemşi } & \text { şkimi-te } & \text { ko-elebuç̧i } \\ \text { rusty needle } & \text { POss.1sG-INs } & \text { EMPH-sew:[1>3]sG.PST.PFV } \\ \text { 'I sew together it with my rusty needle.' }\end{array}$

Hence, the right border of an NP can clearly be identified by inserting a possessive pronoun into the phrase. NP-internal modifiers can thus be formally distinguished from participant-oriented adjuncts following the NP. Compare (8a) with (8b).
a. Ł̌̉̆a cari
şkimi
bimxor
hot bread/meal POSS.1SG eat:1SG.PRS
'I eat my hot meal.'
b. cari ş̌kimi tuža bimxor
bread/meal poss.1sG hot eat:1SG.PRS
'I eat my meal hot.'

In (8a) the adjective tuža 'hot' is part of the NP and functions as an NP-internal modifier to its head noun. The position of şkimi in (8b) shows that the modifier $\check{t} u \check{z} a$ 'hot' is outside the NP. It serves as a clause-level adjunct with object-oriented reading. Although the semantic nucleus of the NP functions as the controller of this participant-oriented adjunct, $\check{t} u \breve{\zeta} a$ 'hot' exhibits no morphological means to show this semantic relation overtly. In this respect as well, Laz contrasts with Georgian.

While participant-oriented adjuncts following their controller NP can be distinguished from NP-internal modifiers, the possessive pronoun insertion test obviously does not work for adjuncts that are placed to the left of their controller-NP. Hence, ťtuža 'hot' in (8a) may either be read as an NP-internal modifier or as a participant-oriented adjunct of its own. In actual utterances, ${ }^{4}$

\footnotetext{
4 Note that Laz is mainly a spoken language. There are no widespread mass media in the language and only a few printed books and journals. Most Laz do not read and write in their language. There is no standard variety.
} 
however, a participant-oriented adjunct construction differs from one with NP-internal modification with respect to prosody. A participant-oriented adjunct may form an intonation unit of its own (see section 7.4.2), while this does not hold for NP-internal modifiers.

\subsection{Depictive and manner expressions}

This section is concerned with participant-oriented expressions of state (i.e. the kind of expression widely used to exemplify depictives) and eventoriented manner expressions. We use the term DEPICTIVE in this section as a convenient shorthand for 'participant-oriented expression of a state', i.e. for a purely semantically defined expression type. As we will see, there is little evidence to support the distinction of two different (formal) constructions for these two kinds of expression.

\subsubsection{Similarities in distribution}

In Laz, there are no segmental means to distinguish manner adverbials and depictives. For manner expressions, compare the adjectives vrosi 'good, well' and evedi in (9), for depictive compare the participle oǩkototeri in (10).

(9) a. vrosi gamă̌edi;

vrosi gamažedi

good look_through:2sG.PST.PFV see:>2SG.FUI

" "Look carefully. You'll see (something)," the men said.' murunక̌xi 032)

b. evedi komoxtil

evedi ko-moxti

quick EMPH-come:2SG.IMP

'Come here quickly!' (W Bienentext 034)

(10)

\begin{tabular}{|c|c|c|c|}
\hline $\begin{array}{l}a-s i \\
e-G E N\end{array}$ & $\begin{array}{l}\text { cindo;(1.9) } \\
\text { surface }\end{array}$ & $\begin{array}{l}\text { oǩkokoťeri } \\
\text { folded_in_half }\end{array}$ & $\begin{array}{l}e o-z u n \backslash \\
\text { on-lie:3sG.PRs }\end{array}$ \\
\hline & & & (Posit \\
\hline
\end{tabular}

The position of an adjunct constituent of any kind is more or less free, i.e. it depends on discourse pragmatic rules. The preverbal position is the preferred position for both depictive and manner expressions with respect to text frequency and in terms of the order usually given in elicited utterances. Note that preverbal position is the preferred slot for focused constituents. For example, interrogative pronouns are obligatorily placed there and cannot be intonationally detached from the predicate: compare (11). 
(11) roma cuma š̌ani noya mu iindru?

yesterday brother poss.2SG market what buy:3SG.PST.PFV

'What did your brother buy on the market yesterday?'

* yoma cuma sǩani mu noya iindru?

In this position, participant-oriented and manner expressions as well as other kinds of constituents tend to have a falling pitch accent with the fall continuing on the following predicate (cf. figures 7.1 and 7.2). Topics are placed utterance-initially.

Depictive expressions may precede or follow their controller, as the examples in (11) illustrate. In (12a), the controller toçi 'rope' precedes the depictive adjunct $\check{k}$ ir $\breve{k} o l e r i$ 'wound up', while in (12b) the controller to to $i$ ' rope' follows the adjunct koteri 'folded'. Note that the depictive expressions in both utterances are prosodically separated from the adjacent constituents. ${ }^{5}$
a. toội ; Ǩirǩoleri ; (o.1)
buçişi
cindo
goozun $\backslash$
toçi ǩrǩkol-eri
buç̧i-şi
cindo
goo-zun
rope wind-PTCP
stump-GEN
surface
on-lie:3SG.PRS

'The rope is on the tree stump in a wound fashion.'

(Posit)

b. boşi ťikina/(o.5) ǩoteri / (1.1) toç̌i goozun।

boşi ṫiǩina ǩoteri toç̧i goo-zun

empty basket fold-PTCP rope on-lie:3sG.PRS

'On an empty basket there is a rope in a folded state.'

(Posit)

Furthermore, depictive expressions may appear in clause-initial position; cf. ǩucxe çunçu 'barefoot' in (13).
ǩuçxe çunçu žari morapay
kuçxe çunç̧u žari moy-ap-ay
foot-naked water bring-CAUS-[3 $>3$ ] SG.PRS
'She sent her barefoot for water.' (W Fadume 009)

Depictive expressions may also be placed after the predicate as is the case with the depictive kuru 'plain' in (14).
nezi bimxor/(o.1) ̌̌uru/
nezi bimxor ǩru
walnut eat:1sG.PRs plain
'I eat the walnuts plain [i.e. without any other food].' (K/G nezi 036)

${ }^{5}$ At this point, it remains to be investigated what kinds of semantic effect correlate with these alternative positions and prosodic breaking. 
These variations in word order are also found with manner expressions. They too may follow the predicate, as shown for the manner adverbial evedi 'quickly' in (15).

$\begin{array}{lllll}\text { (15) Kedir Kedir a; (o.1) } & \text { a } & \text { komoxti } & \text { evedi; } \\ \text { Kedir Kedir a } & \text { a } & \text { ko-moxti } & \text { evedi } \\ \text { Kedir Kedir one } & \text { one EMPH-come:2sG.PST.PFV quick } \\ \text { 'Kedir, Kedir, come on. Quickly!' (W Bienentext 032) }\end{array}$

In post-predicate position, both depictive and manner expressions exhibit the characteristics of afterthoughts, i.e. they constitute a separate intonation unit and follow a prosodic unit with final intonation.

Manner adverbials may also be non-adjacent to the predicate, as is the case in (16), where the interrogative pronoun $m i$ 'who' directly precedes the predicate.

(16) bitumi vrosi mi ompulu?

all well who hide:[3>3]sG.PST.PFV

'Who has hidden everything well?'

In conclusion, we can state that in Laz depictive (participant-oriented) and manner (event-oriented) expressions cannot be distinguished by segmental or distributional means. They would therefore appear to be formally expressed by a single construction type which allows both participantoriented and event-oriented readings, thus exemplifying a general adjunct construction as defined in the introduction to this volume. However, there may be prosodic differences between the two expression types, as further discussed in the next section.

\subsubsection{Prosodic differences?}

In this section, we provide preliminary evidence for the observation that depictive and manner expressions differ with regard to at least one aspect of prosodic marking. In preverbal position, depictives may be intonationally detached from the main predicate of the clause, i.e. they may form an intonation unit of their own. In contrast, manner adverbials cannot be intonationally separated from the predicate in this position. Note that these are very tentative observations, since Laz prosody is still very poorly understood.

In Laz, elements in preverbal position show a strong tendency to form an intonational unit with the following predicate. This holds for adverbials as well as depictive expressions, as the following examples demonstrate. Figure 7.1 


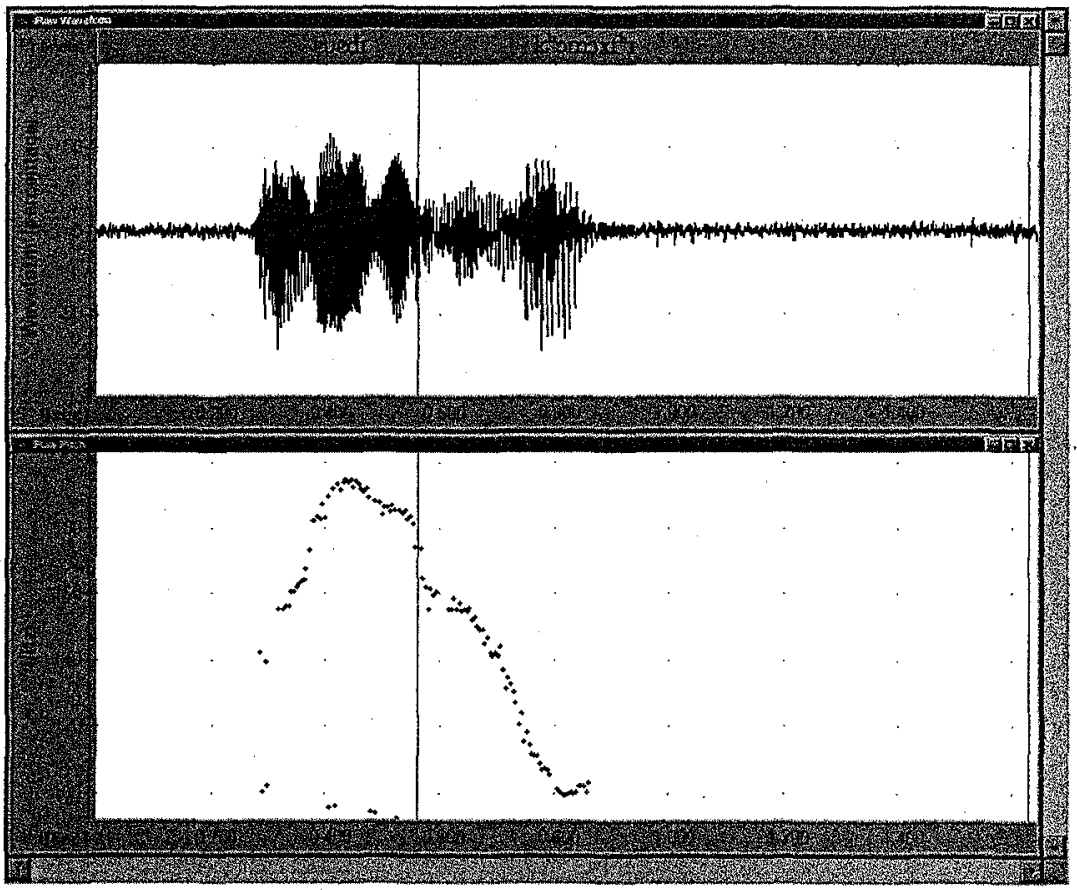

FigURE 7.1 Wave form and pitch extraction for example ( $9 \mathrm{~b}$ )

shows the waveform and pitch extraction for the manner adverbial in (gb) above. The vertical cursor line crossing the graphs indicates the word boundary between the adverb evedi 'quickly' and the predicate komoxti 'come'.

Figure 7.1 clearly shows rising Fø on the first syllable of the manner adverb evedi followed by a fall on the second syllable. The fall continues smoothly into the first syllable of the predicate komoxti.

A continuous contour like the one in Figure 7.1 is found on most of the preverbal depictive expressions in our corpus, as well. Figure 7.2 illustrates the Fø contour of the depictive expression oǩkoteri 'folded' given in example (10) above. The relevant section of the contour is marked with a vertical line in the figure. Once again the falling contour on the depictive participle oǩkoteri 'folded' is continued on the following predicate eozun 'it lies on sth.'.

In contrast to adverbial manner expressions, with depictive expressions we also find examples in our corpus where the depictive expression is intonationally detached from the following predicate by a clear break in the 


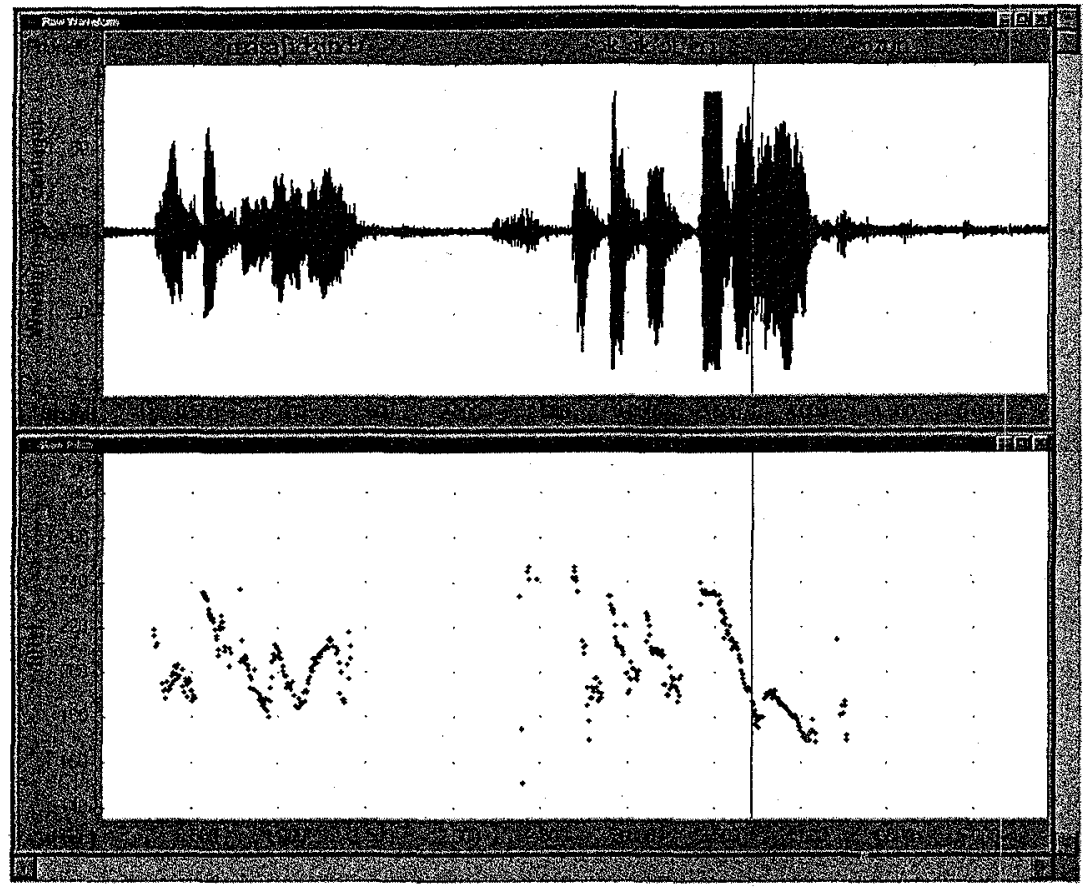

FIGURE 7.2 Wave form and pitch extraction for example (10)

Fø contour, as is illustrated in (17) and figure $7.3 .{ }^{6}$

(17) gzalineri/ (0.6) mendaxtey 1 by_foot go_to:3PL.PST.PFV

'They went there by foot.' (K/G askerepe 111)

As Figure 7.3 illustrates, the Fø contour in this case is quite the opposite of those given in Figures 7.1 and 7.2. In figure 7.3 the Fø clearly rises on the last syllable of the depictive gzalineri by foot' (in all likelihood realizing a highrising boundary tone). The onset pitch of the following predicate, mendaxtey, is clearly much lower and in the mid range typical for the onset of a new intonation unit.

As for manner adverbials, we did not find an Fø contour in our corpus comparable to the one illustrated in Figure 7.3 for depictive expressions. Therefore, we tested this intonation pattern by elicitation. The test utterance

6 The semantic effects of the prosodic break need further investigation. 


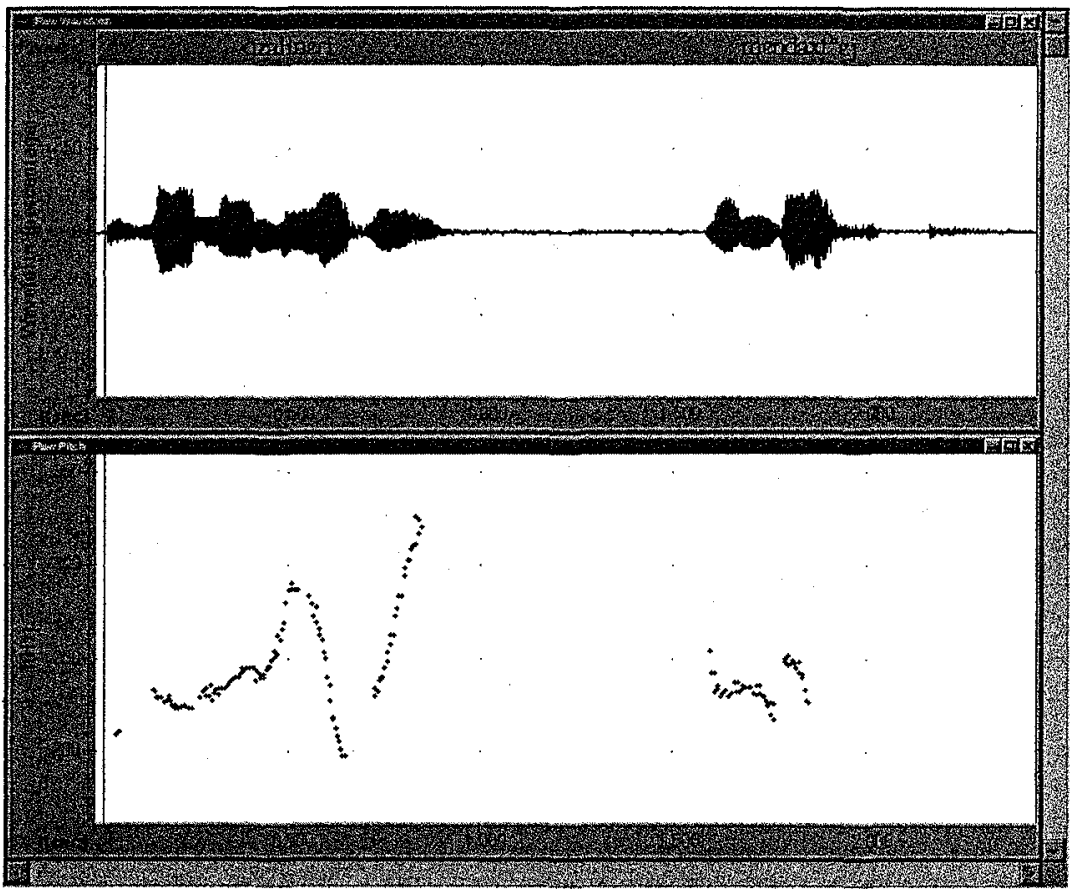

FIGURE 7.3 Wave form and pitch extraction for example (17)

(18) was taken from a narrative in our corpus. In the original utterance, the manner adverbial vrosi 'well' and the predicate dvompuli 'hide it' are part of a single continuous pitch movement (see Figure 7.4).

(18) bitumi ozxone vrosi dvompuli/ bitumi ozxone vrosi dv-ompuli all attic good EMPH-hide:[2<3]SG.IMP 'Hide everything well in the attic.' (K/G askerepe 104)

For our test, the second author of this chapter, a native speaker of Laz, produced the utterance illustrated in (19), i.e. a high-rising, unit-final pitch on the manner adverbial vrosi followed by a break and a mid range onset on the predicate dvompuli.

\section{(19) bitumi osxone vrosi/ dvompuli} all attic well EMPH-hide:[2>3]sG.IMP

'Hide everything well in the attic.' 


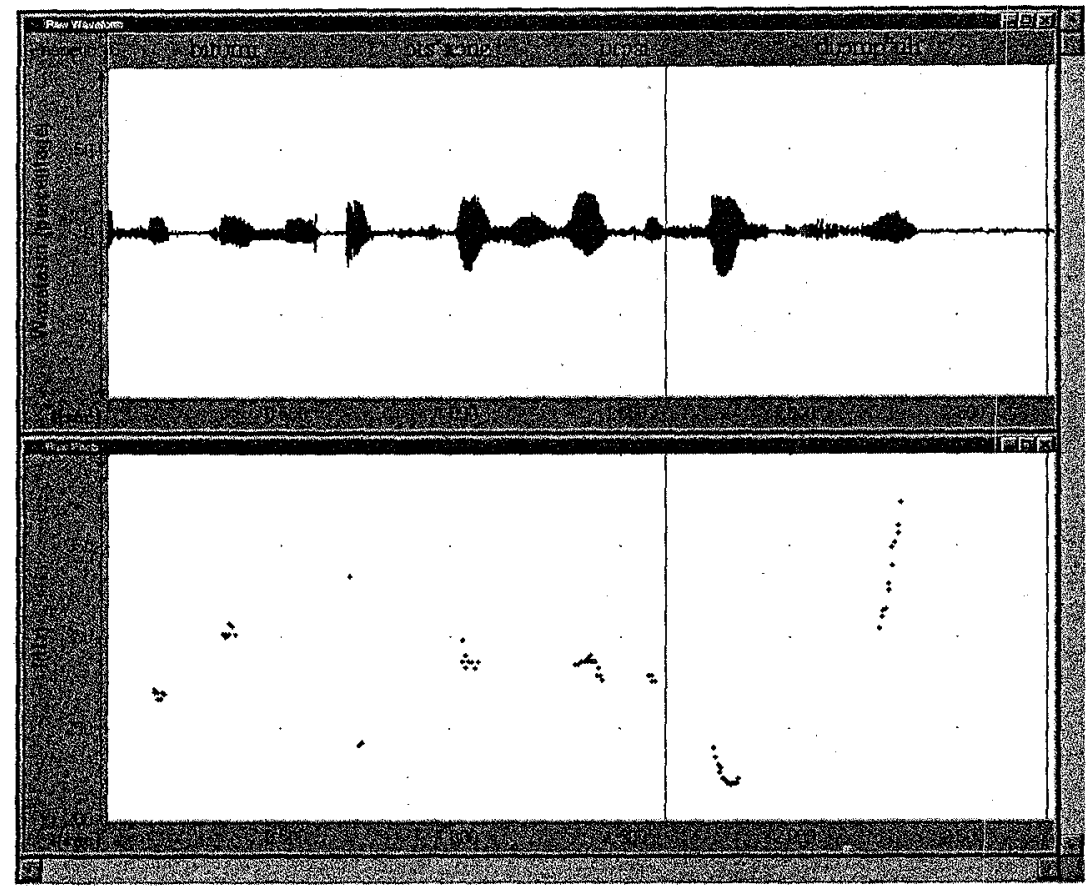

Figure 7.4 Wave form and pitch extraction for example (18)

This test utterance was played to two other native speakers. Both speakers clearly rejected it on the grounds that it was 'not sounding right'. Both of them only accepted intonation patterns close to the one found in (18), i.e. with no intonational break.

To conclude, manner adverbials and depictive expressions appear to be very similar with respect to (the lack of overt) marking and distribution. But depictive expressions may constitute intonation units of their own (typically with progredient final intonation) when in pre-predicate position. In contrast, sequences of manner adverbial plus predicate strongly disfavour prosodic breaking. Preliminary analyses of other adverbial expressions support the impression that the restrictions concerning possible intonation patterns demonstrated for manner adverbials in this section also hold for other adverbials. But the intonational properties of adverbial and depictive expressions definitely need further investigation. For the time being, we consider them to instantiate a single construction type, i.e. a general adjunct construction. 


\subsection{Other types of adjunct that allow participant-oriented readings}

This section provides data on other types of expressions which share semantic characteristics with depictive expressions in Laz. Section 7.5.1 investigates the semantic range of the instrumental case, section 7.5.2 discusses uses of expressions marked with motative case, and section 7.5.3 deals with locational nouns. For all three kinds of expressions, we will argue that no clear boundary can be drawn between participant-oriented and eventoriented constructions.

\subsubsection{Instrumentals}

The suffix -te mainly marks NPs referring to the instrument of an event. Its use is restricted to non-human referents (see Kutscher 2001: ch. 5 for details). In addition to encoding an instrument, the suffix covers cause $(20,21)$, purpose (22), and accompaniment (23) readings. In the following, we discuss these uses in more detail.

An instrumental case may mark adverbials of cause, as is the case with the verbal noun obiru 'play' in (20) which gives the reason why the speaker returned home late.

$$
\begin{array}{ll}
\text { himndya / (o.1) obirute leba domaul } \\
\text { him-ndya } & \text { obiru-te leba do-mau } \\
\text { DEM-day } & \text { play:vN-INs late EMPH-become:>1SG.PST.PFV } \\
\text { 'On this day I was late because of playing.' (W Kuhtext 006) }
\end{array}
$$

Instrumentals of cause are not restricted to event-oriented uses. Compare the noun ş̌kurina 'fear' in instrumental case in (21). The example is from a narrative about a mother and a daughter harvesting tea up in the mountains away from their village. On their way home they reach a river and as dusk comes, the mother begins her evening prayer. While the mother is praying, the daughter hears some strange noises and thinks the river ghosts are coming to get her. The mother, knowing that her daughter is a timid person and would prefer to go home and not pray at the bank of the river, thinks that her daughter is hallucinating and says:

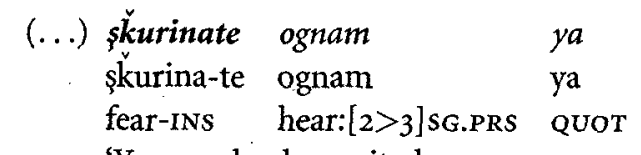
'You only hear it because you are frightened.'
$(\mathrm{K} / \mathrm{G}$ gecekulesa 028) 
In this context, the nominal şurinate denotes a mental state of the actor of the predicate ognam 'you hear it', i.e. the daughter, and hence functions as a participant-oriented expression.

The same holds for the instrumental phrase parate 'with money' in (22) which denotes the purpose of the activity of the actor participant of the main predicate $p \breve{s}$ ilum 'I pluck':

$\begin{array}{lll}\text { çayi; (o.1) } & \text { parate } & \text { pǔilum } \\ \text { çayi } & \text { para-te } & \text { pǔilum } \\ \text { tea } & \text { money-ıNs } & \text { pluck:1sG.PRs }\end{array}$

'I am harvesting tea for money [in order to get money].'

The instrumental in (22) also relates to the mental state of the actor or rather, it encodes that the actor is accompanied by a certain mental state, namely the thought of money. Hence, more literally one may translate (22) as 'I pluck tea with money on my mind'.

An instance of the participant-oriented use of the accompaniment meaning of the instrumental is the instrumental phrase $\check{k} a$ kalite 'with a stone' in (23).

(23) mbuli ǩaǩalite ceş̌̌idu

mbuli ǩkakalite ceş̌idu

cherry stone-INS swallow:3SG.PST.PFV

'S/he swallowed the cherry with its stone.'

As can be shown by the insertion of a possessive pronoun in (24) (see section 7.2 above), $k_{a}$ kali 'stone' in (23) is not internal to the object NP mbuli. It forms a constituent of its own and functions as a participant-oriented adjunct.

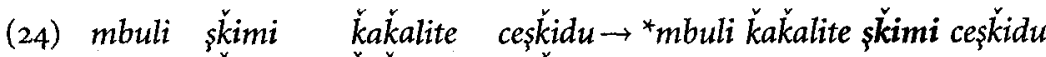

mbuli şkimi ǩkakali-te ceşkidu

cherry Poss.1sG pip-INs swallow:3SG.PST.PFV

'S/he swallowed my cherry with its stone.'

In some cases the instrumental expression is semantically vague as to a participant- or event-oriented reading, as seen in (25).
(25)
క̌uneri
kibrite
cari
imxoy
3un-eri
kibri-te cari
imxoy
hurt-PTCP teeth-INS meal/bread eat:3sG.PRs
'S/he eats the meal with hurting teeth.'

In (25), the hurting teeth of the actor are the instruments of the eating process, i.e. on the one hand the expression is event-oriented. Simultaneously, the instrumental phrase in (25) refers to the physical state of the eater and therefore is participant-oriented. 
To conclude, the instrumental allows event-oriented as well as participantoriented uses. Moreover, in some instances the orientation of the instrumental is in fact vague. Hence, Laz instrumentals instantiate what Himmelmann and Schultze-Berndt (Ch. 1, this volume) call a general adjunct construction. In the following section, we will show that comparable findings hold for motative phrases.

\subsubsection{Motatives}

The term motative originates in the grammar of Pazar-Laz written by Rosen (1844) and captures the particular semantics of this case, which only encodes that the referent of a nominal thus marked has moved, but it is vague with respect to whether the referent is moving towards a goal (as in (26a); see also (4a) above) or moves away from a source, as in (26b).
a. bere oxori-şa amulun bere oxori-şa amo-ulun child house-Mot into-go:3sG.PRs 'The child goes inside the house.'
b. bere oxorişa
gamulun
bere oxori-şa
gamo-ulun
child house-mot out-go:3sG.PRs
'The child goes out of the house.'

The direction of movement is usually specified by a spatial prefix to the predicate, e.g amo- 'into' in (26a) or gamo- 'out' in (26b).

Motative phrases most frequently are event-oriented, as in the preceding examples. In some cases, however, we have found motative-marked phrases which clearly have participant-oriented semantics. In these cases, the predicate denotes an event of emission and the motative relates to the source of this event; compare (27) for illustration.

$$
\begin{aligned}
& \text { p̆armakluyepeşa buoxam } \backslash \text { naana } \\
& \text { p̆armaklu yi-pe-şa buoxam nana } \\
& \text { railings-PL-MOT call:[1>3]sG.PRs mother } \\
& \text { 'I called her from the railings: "Mother."' }
\end{aligned}
$$

In (27), the narrator of the story is accidentally caught in a storehouse and tries to call her mother so that she may be released. The actor of the predicate buoxam 'I call her' is behind the railings of the storehouse, while the undergoer, the person called, is outside the storehouse, coming down the street. Interestingly, the motative phrase in these participant-oriented uses expresses the 
location of the controller, not its movement towards a goal or from a source. The calling, however, is directed away from the controller in (27), which makes the controller the source of the event expressed in the predicate. Hence, the motative phrase at the same time is also event-oriented. Compare (28), where the caller comes to the storehouse and calls a person standing behind the storehouse's railings. In this case the motative-marked phrase is purely eventoriented, denoting the direction of the calling but not the location of the caller.

$\begin{array}{lll}\text { serende-şa } & \text { moxtu } & d o \\ \text { storehouse-Mot } & \text { come:3SG.PST.PFV } & \text { and }\end{array}$

р̆armakluyepe-şa uoxu

railings-Mor call[3>3] sG.PST.PFV

'S/he came to the storehouse and called to her towards the railings.'

To conclude, Laz has a general adjunct construction of location-the motative-marked phrase. These motative phrases may be used to express the location of a participant and at the same time are event-oriented in that they indicate the direction to which the event is oriented.

\subsubsection{Locational nominals}

In addition to the general adjunct construction of location dealt with in the preceding section, Laz also has expressions in which the location of a participant is expressed by an unmarked locational nominal, e.g. cindo 'top' in (29).

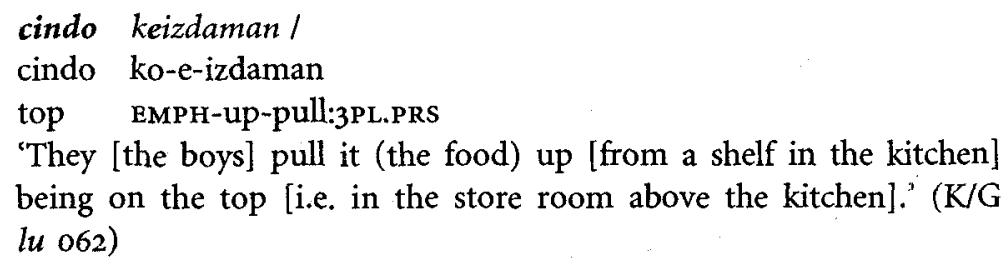
$l u$ 062)

The landmark expression cindo 'top' in (29) denotes the location of only one of the participants in the event, namely the boys. Conversely, the preverb $e$ - 'up' denotes the direction of the food which is being pulled up, i.e. the food is on its way up to the boys. With respect to participant orientation, Laz locational nominals, which consist of a locative adverb plus the suffix - ndo, differ from the locative adverbs from which they are derived. ${ }^{7}$ The latter are compatible with

7 Landmark expressions with the suffix - ndo like cindo 'top' are nominals. They can appear in core argument function and may be modified by a genitive NP (cf. (15a)).

(i) cindo musi buzi diu

cindo muşi buz do-iu

top poss.3sG ice MOD-become:3SG.PST.PRF

'Its surface became ice.' (K/G promepe oo6) 
spatial preverbs of the same semantic domain. Thus, the locative adverb cin 'up' in (30) specifies or emphasizes the spatial semantics of the preverb $e$ - 'up'.

\section{(30) cin e-izdaman \\ up up-pull:3PL.PRS \\ 'They pull it up [above].'}

Locative adverbs are event-oriented only. The adverb cin 'up' denotes the upward movement of the food and, in contrast to the locational nominal in (29), does not relate to the location of the actor. The puller in (30) may as well transport the food away from herself with the help of a block and tackle.

Since the nominal expressions may be participant-oriented, there is a functional difference between locational adjunct expressions containing a nominal with - ndo suffix and those with an adverb. Nevertheless, locational nominal expressions cannot be analysed as a genuine depictive construction, since they may also be used as locative modifiers. In this function, the locational expression refers to the location of the event to which the predicate relates. Compare (31), where the locational expression oxorişi cindo 'on top of the house' relates to the place where the event of the speaker's spreading the hazelnuts is taking place.
(31) oxori-şi
cindo ntxiri
goo-bobram
house-GEN top hazelnut on-lie_mass:[1>3]sG.PRS
'I spread hazelnuts on top of the house.'

Laz locational nominal expressions may also serve to relate only to a part of the event expressed by the predication (i.e. internal modifier function, $\mathrm{cf}$. Maienborn (2001)). Compare (32) for illustration.

\section{(32) ǩkafri cindo me-buçadi \\ nail top at-hammer:[1>3] sG.PST.PFV \\ 'I hammered the nail on the upper part [of the door].'}

The locational nominal cindo 'top' in (32) does not relate to the location of the whole event, since only the hammering and the object of the hammering is located on the upper part of the door. The actor of the event is not located there. Hence, the locational nominal specifies an internal aspect of the event

Conversely, bare forms, i.e. expressions without -ndo suffix, are locative adverbs. They cannot appear in core argument function (see Kutscher 2001, chapter 3 for details) and cannot be modified by a genitive NP.

(ii) ntxiri cin goobobram $>$ *oxori-şi cin

hazelnut above spread.on:[i>3]sG.PRS

'I spread hazeinuts above.' 
but does not locate the event as a whole. In this function, the locational nominal is both participant-oriented (relating to the location of the nail, but not the actor) and event-oriented.

Locational nominals can also be used as frame-setting expressions (Maienborn 2001). In this function, the locational nominal does not relate to the location of the event directly but sets a frame for it. Compare (33), where a young woman is instructed by her mother-in-law how to escape from the Russian soldiers who are about to invade the village.

oxori doloxendo Ineǩnape pencerepe vrosi; (o.3)
oxori doloxendo neǩna-pe pencere-pe vrosi
house inside
doçadi / $(0.5)(\ldots)$
do-oçadi
EMPH-nail: $[2>3]$ sG.PST.PFV
'Inside the house, nail the doors and windows well...
askerepe 098-102)

The locational expression oxori doloxendo 'inside the house' in (33) is intonationally detached and has a progredient intonation contour. It sets the frame of the hammering event denoted in the following intonation unit neǩnape pencerepe vrosi doçadi 'nail the doors and windows well'.

In sum, locational nominal expressions in Laz serve the three different functions which Maienborn (2001) argues to be typical for locative adjuncts: internal and external modification and frame-setting. With respect to these functions, locational nominal expressions in Laz are event-oriented. In addition, locational nominals in some uses exhibit purely participantoriented readings. Hence, locational nominal expressions in Laz are another instance of the general adjunct construction.

\subsection{A genuine depictive construction: distributive numerals}

This section deals with quantifier expressions. On constructional grounds, these have to be divided into two subclasses in Laz: collective quantificational and distributive quantificational expressions.

Collective quantificational expressions are similar in construction to the manner expressions discussed in section 7.4 above. They are construed with unmarked quantifiers such as xvala 'alone' in (34) and may have participant-oriented readings (34a) or are vague with respect to participant and event orientation (34b). 
(34) a. xvala eş̌ka-ftare।

alone up-go:1SG.FUT.PFv

'We will go up alone.' (K/G xvala 004)

b. ̌̌sşi coyi xvala psǩkudur

winter village alone live:1SG.PRS

'In the winter I live on my own in the village.'

Bare numerals, however, can only be interpreted as event-oriented. Compare the numerals ar 'one' and cur 'two' in (35), which denote the frequency of the soldiers' comings.

$\begin{array}{lll}\text { askerepe a moxtey; } & \text { cu moxtey/ } \\ \text { askere-pe ar moxtey } & \text { cur moxtey } \\ \text { soldier-PL one come:3PL.PST.PFV two come:3PL.PST.PFV } \\ \text { 'The soldiers came once, they came twice.' }\end{array}$

Reduplicated numerals, in contrast, are clearly participant-oriented, as in (36).

$$
\begin{array}{ll}
\text { askerepe } & \text { curcur moxtey } \\
\text { soldiers two:RDP } & \text { come:3PL.PST.PFV }
\end{array}
$$

'The soldiers came in pairs'

These participant-oriented numeral expressions can only have a distributive meaning (e.g. 'two by two' in the above example) and cannot be used to express the total number of referents of the phrase, ${ }^{8}$ like the German construction with $z u$ 'to' + numeral. ${ }^{9}$

Other participant-oriented quantifiers may also be reduplicated, compare (37).

$$
\begin{array}{ll}
\text { xvalaxvala / (2.3) } & \text { bulur } \backslash \\
\text { xvala:RDP } & \text { bulur } \\
\text { alone } & \text { go:ISG.PRS } \\
\text { 'I walk totally alone.' } \quad \text { (K/G inonu 058) }
\end{array}
$$

In these cases, however, the reduplication seems to be emphatic or, in the case of Turkish loans, may be induced by the Turkish source construction. Reduplication in these emphatic cases, however, is non-obligatory and hence not a genuine constructional means to encode participant orientation. In contrast, for numerals functioning as participant-oriented adjuncts

\footnotetext{
${ }^{8}$ When used in argument position, numerals show a special form with a suffix (for details, see Kutscher 2001: ch. 3.2.2).

9 Compare German Sie kamen zu zweit (3.PL came at two) 'The two of them came', referring to exactly two persons coming, in contrast to the distributive construction Sie kamen in Paaren (3.PL came in pairs) 'They came two by two", referring to more than two persons.
} 
reduplication is obligatory. Therefore, we would argue that reduplicated numeral expressions are an example of a genuine depictive construction. ${ }^{10}$

\subsection{On expressing role and life stage in Laz}

Expressions of role such as I got the book as a present are often considered to be typical examples of depictive secondary predicate expressions. Interestingly, adjunct constructions of this type cannot be found in Laz. Role expressions in Laz always have to be biclausal constructions. Both the role predication and the main predication form independent main clauses, each containing a finite verb. An example is given in (38).

$\begin{array}{llll}\text { baba şkimi doktori on } \backslash \text { hastahane içalişay! } \\ \text { baba şkimi doktori on } & \text { hastahane içalişay } \\ \text { father Poss.1SG doctor be:3sG.PRs hospital work:3sG.PRS } \\ \text { 'My father is a doctor. He works at the hospital.' }\end{array}$

Life-stage expressions, which often occur in the same type of construction as role expressions (e.g. she lived in Paris as a child), occur in two types of construction in Laz. The first type of life stage construction is again biclausal in nature. The life stage is expressed in a finite copula construction such as borti 'I was' in (39). In contrast to biclausal role expressions, however, the life-stage expression in biclausal life-stage constructions is the predicate of a subordinate clause marked by the motative suffix $-s a$. The motative in these constructions, together with imperfective aspect, expresses the simultaneity of the two predications.

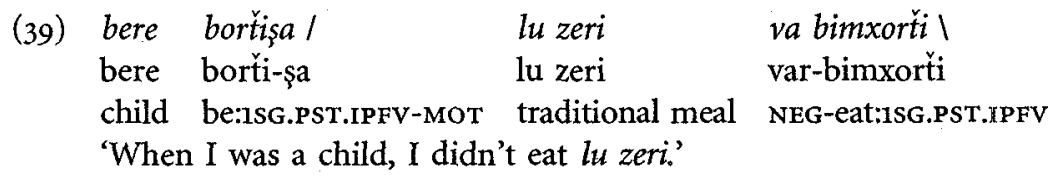

The subordinate clause construction is obligatory for this type of life-stage expression and not merely an alternative as is the case e.g. in English, where

\footnotetext{
10 Subject to the condition that distributive numeral expressions are analysed as depictive expressions. McGregor ( $\mathrm{Ch} .5$, this volume) provides a detailed discussion of numerative expressions in some Australian languages. As he points out, distributive quantificational expressions (or, in his terms, iterative co-participation) do not as easily qualify as depictive expressions. Although semantically they are participant-oriented and predicative, at least in some of the Australian languages under consideration, they lack agreement with the designated controller. In the Panoan language Shipibo-Konibo (Valenzuela, Ch. 8, this volume), on the other hand, numerals in distributive function show agreement with the controller.
} 
the subordinate clause when I was a child could be turned alternatively into the depictive construction as a child.

The fact that the subordinate clause is marked by a suffix expressing simultaneity which is similar in form to the motative case marker $-\xi \xi a$ (see section 7.3.2) gives rise to the question of whether this construction is a converb construction. Since the finite verb of the subordinate clause allows for an explicit subject NP and may have complements that are not coreferential with a participant of the matrix clause, we analyse the suffix in this use as a temporal conjunction. Compare (40), where nana şkimi 'my mother' is the subject of the predicate komoxtu 'she came'.

(40) nana ş̌kimi oxori ko-moxtu-şa
mother POss.1SG house EMPH-come:3SG.PST.PFV-MOT
kitabi golobioni
book read:1SG.PST.PFV
'When my mother came home, I was reading a book.'

The second type of life stage expressions has two variants. It may either contain a temporal adverb, as in (41b), or, for expressions denoting the exact age of the controller, a numeral is combined with the participle ̌̌aneri 'of age', as in (41a).
$\begin{array}{lll}\text { a. cur žaneri } & \text { osinapu ceboçi } \\ \text { cur žan-eri } & \text { osinapu ceboçi }\end{array}$
two year-PTCP speak:VN begin: $[1<3]$ SG.PST.PFV
'Two years old I began to speak.'
b. ordo yuru
early die:3SG.PST.PFV
'S/he died young.'

This kind of life stage construction is an instance of the general adjunct constructions discussed in sections 7.4 and 7.5 .

\subsection{Conclusion}

In this chapter we have presented an overview of expressions in Laz which allow participant-oriented readings. We have argued that although Laz has a wide range of expressions of this kind, there are no unique segmental or distributional means marking a given construction as a genuine depictive construction. The single major exception to this claim is reduplicated numerals functioning as distributive quantifiers (section 7.6). The fact that otherwise there appears to be no genuine depictive construction in Laz seems 
to be based on two factors: (a) the lack of case agreement on various levels, including agreement between controllers and participant-oriented adjuncts; (b) the fact that participant-and event-oriented adjuncts share essentially the same distributional possibilities. They also appear to share essentially the same possibilities of prosodic marking, in particular the ability to appear in intonation units of their own. The only possible exception with regard to prosody pertains to the observation discussed in section 7.4 that manner adverbials in pre-predicate position cannot be separated prosodically from the following predicate. However, this observation as well as other features of prosodic marking and packaging are still in need of much deeper exploration. 


\section{References}

Aarts, Bas (1995). 'Secondary predicates in English', in Bas Aarts and Charles F. Meyer (eds), The Verb in Contemporary English: Theory and Description. Cambridge: Cambridge University Press, 75-101.

Adams, Bruce (1983). A Tagmemic Analysis of the Wolaitta Language. Ph.D. dissertation, University of London.

Agbadja, Kokou Sénamé (1983). 'Pour une approche nouvelle des prétendus “adverbes" Eße', Afrique et Langage 19: 32-51.

Aikhenvald, Alexandra Y., and Dixon, Robert M. W. (eds) (to appear). Serial Verb Constructions in Crosslinguistic Perspective. Oxford: Oxford University Press.

Aissen, Judith (2000). 'A serial verb construction in Tzotzil', http://ling.ucsc.edu/ Jorge/aissen.

Ameka, Felix K. (1991). Ewe: its Grammatical Constructions and Illocutionary Devices. Ph.D. dissertation, Australian National University.

- (1992). 'Focus constructions in Ewe and Akan: a comparative perspective', in Chris Collins and Victor Manfredi (eds), Proceedings of the Kwa Comparative Syntax Workshop MIT 1992. Cambridge, Mass.: MIT Working Papers in Linguistics $17,1-25$.

(2001). 'Ideophones and the nature of the adjective class in Ewe', in Voeltz and Kilian-Hatz (2001: 25-48).

- (2002). 'Constituent order and grammatical relations in Ewe in typological perspective', in Kristin Davidse and Beatrice Lamiroy (eds), Nominative/Accusative. Amsterdam: Benjamins, 319-52.

- (2003a). 'Prepositions and postpositions in Ewe (Gbe): empirical and theoretical considerations', in Patrick Sauzet and Anne Zibri-Hertz (eds), Typologie des langues d'Afrique et universaux de la grammaire. Paris: L'Harmattan, 41-67. - $(2003 \mathrm{~b})$. 'Today is far: situational anaphors in overlapping clause constructions in Ewe', in Mary E. Kropp Dakubu and Emmanuel K. Osam (eds), Studies in the Languages of the Volta Basin 1. Legon: Department of Linguistics, University of Ghana, 9-22.

- (to appear). 'Ewe serial verb constructions in their grammatical context', in Aikhenvald and Dixon (to appear).

and Schultze-Berndt, Eva (2000). 'Adverbialiser or predicate(ion) marker? Ewe $-i$ and its relatives in a typological perspective', Third World Congress of African Linguistics, Université du Benin, Lomé, Togo, August 2000.

Amha, Azeb (2001). The Maale Language. Leiden: Centre for Non-Western Studies. — and Dimmendaal, Gerrit J. (to appear). 'Verbal compounding in Wolaitta and self-organizing principles in languages', in Aikhenvald and Dixon (to appear). 
Amuzu, Evershed K. (1993). Three-place predicates in Ewe. MA thesis, University of Ghana, Legon.

Andrews, Avery (1982). 'A note on the constituent structure of adverbials and auxiliaries', Linguistic Inquiry 13(3): 313-17.

Ansre, Gilbert (1966). The Grammatical Units of Ewe: A Study of their Structure, Classes and Systems. Ph.D. dissertation, University of London.

Apridoni ze, Šukia (1986). Sițquatganlageba Axal Kartulš (XIX-XX sauk. prozis mixedvit. marțivi çinadadeba) (EI). Tbilisi: Mecniereba.

Arnott, David W. (1970). The Nominal and Verbal Systems of Fula. Oxford: Clarendon Press.

Asher, Nicholas (1993). Reference to Abstract Objects in Discourse. Dordrecht: Kluwer. Austin, Peter (1981a). A Grammar of Diyari, South Australia. Cambridge: Cambridge University Press.

- (1981b). 'Switch-reference in Australia', Language 57(2): 309-34.

- (ed.) (1988). Complex Sentence Constructions in Australian Languages. Amsterdam: Benjamins, 205-18.

- (1997). Texts in the Mantharta Languages, Western Australia. Tokyo: Institute for the Study of Languages and Cultures of Asia and Africa.

Bartsch, Renate (1972). Adverbialsemantik. Frankfurt a. Main: Athenäum.

- - (1976). The Grammar of Adverbials. Amsterdam: North-Holland.

Basilaia, Niḳandre (1966). 'Prediḳațuli gansazyvrebis šesaxeb Axal Kartulši’', Soxumis $\dot{P}$ edagogiuri Instituțis Šromebi 18-19: 257-71.

Bayer, Samuel (1997). Confessions of a Lapsed Neo-Davidsonian. New York: Garland. Behaghel, Otto (1923). Deutsche Syntax. Eine geschichtliche Darstellung. Heidelberg: Winter.

- (1928). Geschichte der deutschen Sprache, 5th edn. Berlin: de Gruyter.

Bhatt, Christa, and Lindlar, Markus (eds) (1998). Alles Kölsch. Eine Dokumentation der aktuellen Stadtsprache in Köln. Bonn: Bouvier.

Biblia (1989). Biblia. Tbilisi: Sakartvelos Sapatriarko.

Bodomo, Adams (1997). Paths and Pathfinders: Exploring the Syntax and Semantics of

Complex Verbal Predicates in Dagaare and Other Languages. Ph.D. dissertation, Norwegian University of Science and Technology, Trondheim.

Boeder, Winfried (1995). 'Suffixaufnahme in Kartvelian', in Frans Plank (ed.), Double Case: Agreement by Suffixaufnahme. New York: Oxford University Press, 151-215.

- (1999a). 'Attribution in Georgian', in Helma van den Berg (ed.), Studies in Caucasian Linguistics: Selected Papers of the Eighth Caucasian Colloquium. Leiden: Universiteit Leiden, 50-9.

- $(19996)$. 'Some notes on the Georgian resultative', in Werner Abraham and Leonid Kulikov (eds), Tense-Aspect, Transitivity and Causativity. Amsterdam: Benjamins, $117-39$.

- (2002). 'Syntax and morphology of polysynthesis in the Georgian verb', in Nicholas Evans and Hans-Jürgen Sasse (eds), Problems of Polysynthesis. Berlin: Akademie, 87-111. 
and Schroeder, Christoph (1998). 'Attribution und sekundäre Prädikate im Sprachvergleich: Deutsch, Englisch, Kurdisch, Georgisch, Türkisch', Sprachtypologie und Universalienforschung 51(3): 207-27.

Bohnenberger, Karl (1913). Die Mundart der deutschen Walliser im Heimattal und in den Aussenorten. Frauenfeld: Huber.

Bolinger, Dwight (1971). The Phrasal Verb in English. Cambridge, Mass.: Harvard University Press.

Braune, Wilhelm (1987). Althochdeutsche Grammatik, 14th edn. Tübingen: Niemeyer. Bresnan, Joan (1982). 'Control and complementation', Linguistic Inquiry 13(3): 343-434.

and Mchombo, Sam (1986). 'Grammatical and anaphoric agreement', in Anne Farley, Peter Farley, and Karl-Erik McCullough (eds), Papers from the Parasession on Pragmatics and Grammatical Theory. CLS 22, Part 2. Chicago: Chicago Linguistic Society, 278-97.

Breu, Walter (1994). 'Interactions between lexical, temporal and aspectual meaning', Studies in Language 18(1): 23-44.

Bruce, Les (1984). The Alamblak Language of Papua New Guinea (East Sepik). Canberra: Pacific Linguistics.

Brun, Leo (1918). Die Mundart von Obersaxen im Kanton Graubünden. Lautlehre und Flexion. Frauenfeld: Huber.

Bucheli Berger, Claudia, and Glaser, Elvira (2002). 'The syntactic atlas of Swiss German dialects: empirical and methodological problems', in Sjef Barbiers, Leonie Cornips, and Susanne van der Kleij (eds), Syntactic Microvariation. http:// www.meertens.knaw.nl/books/synmic/

(2004). 'Zur Morphologie des (ko)prädikativen Adjektivs und Partizip II im Alemannischen und Bairischen', in Franz Patocka and Peter Wiesinger (eds), Morphologie und Syntax deutscher Dialekte und Historische Dialektologie des Deutsch. Vienna: Praesens.

Burçuulaze, Tea (2002). 'Predikațuli gansazyvrebis "orgvari" bunebis taobaze Kartulši'/The double nature of the predicate complement in Georgian' (Résumé 55), Saenatmecniero 3iebani 13: 50-5.

$B W B$ : Bayerisches Wörterbuch (1997). Herausgegeben von der Kommission für Mundartforschung. Heft 3. Munich.

Carlson, Gregory N. (1977). Reference to Kinds in English. Bloomington: Indiana University Linguistics Club.

and Pelletier, Francis J. (eds) (1995). The Generic Book. Chicago: University of Chicago Press.

Carrier Duncan, Jill, and Randall, Janet H. (1992). 'The argument structure and syntactic structure of resultatives', Linguistic Inquiry 23(2): 173-234.

Chierchia, Gennaro (1995a). Dynamics of Meaning. Chicago: University of Chicago Press.

(1995b). 'Individual-level predicates as inherent generics', in Carlson and Pelletier (1995: 176-223). 
Chomsky, Noam A. (1985). The Logical Structure of Linguistic Theory. Chicago: University of Chicago Press.

- (1999). Derivation by Phase. MIT: Occasional Working Papers in Linguistics 18. Čikobava, Arnold, et al. (eds) (1950-64). Kartuli enis ganmartebiti leksikoni. Tbilisi: SSSR Mecnierebata Aḳademiis gamomcemloba.

Cinque, Guglielmo (1999). Adverbs and Functional Heads: A Cross-Linguistic Perspective. Oxford: Oxford University Press.

Clark, Marybeth (1996). 'Where do you feel? Stative verbs and body-part terms in mainland Southeast Asia', in Hilary Chappell and William McGregor (eds), The Grammar of Inalienability. Berlin: de Gruyter, 529-64.

Clauss, Walter (1929). Die Mundart von Uri. Laut- und Flexionslehre. Frauenfeld: Huber.

Coates, Jennifer (1983). The Semantics of the Modal Auxiliaries. London: Croom Helm. Collins, Chris (1993). Topics in Ewe Syntax. Ph.D. dissertation, MIT.

Cootes, Sandra (1989). 'Grammatical and anaphoric agreement in Sesotho'. MS.

Corbett, Greville (1998). 'Morphology and agreement', in Andrew Spencer and Arnold M. Zwicky (eds), The Handbook of Morphology. Oxford: Blackwell, 191-205. Craig, Colette G. (1977). The Structure of Jacaltec. Austin: University of Texas Press. Dale, Desmond (1972). Shona Companion. Gwelo, Zimbabwe: Mambo Press.

Dauwalder, Hans (1992). Haslitiitsch. Wie mma s seid und cha schriiben. Eine haslideutsche Kurzgrammatik. Meiringen: Gemeinnütziger Verein Meiringen.

Davidson, Donald (1967). 'The logical form of action sentences', in Nicholas Rescher (ed.), The Logic of Decision and Action. Pittsburgh: University of Pittsburgh Press, 81-95. Reprinted in Davidson, Donald (1980), Essays on Actions and Events. Oxford: Clarendon Press, 105-22.

Davitiani, Aḳaḳi (1973). Kartuli enis sințaksi I. Sințaksis zogadi saḳitxebi. Marțivi çinadadeba. Tbilisi: Ganatleba.

Topuria, Varlam, and Kaldani, Maksime (1957). Svanuri prozauli tekstebi II: Balskvemouri ḳilo/Svanskie prozaičeskie teksty II: Nižnebal'skoe narečie (= Masalebi Kartvelur enata šesçavlisatvis III) (SMA, EI). Tbilisi: SMA gam-ba.

Dechaine, Rose-Marie (1993). 'Serial verb constructions', in Joachim Jacobs, Arnim von Stechow, Wolfgang Sternefeld, and Theo Venneman (eds), Syntax: An International Handbook of Contemporary Research, vol. i (Berlin: de Gruyter), 789-825.

Delfitto, Denis, and Bertinetto, Pier Marco (2000). 'Word order and quantification over times', in Higginbotham et al. (2000: 207-43).

Dench, Alan C. (1988). 'Complex sentences in Martuthunira', in Austin (1998: 97-139).

- (1991). 'Panyjima', in Robert M. W. Dixon and Barry J. Blake (eds), Handbook of Australian Languages, vol. iv. Melbourne: Oxford University Press, 125-243.

- (1995). Martuthunira: A Language of the Pilbara Region of Western Australia. Canberra: Pacific Linguistics.

Diesing, Molly (1992). Indefinites. Cambridge, Mass.: MIT Press. 
Dieth, Eugen (1986). 'Schwyzertütschi Dialäktschrift', in Christian Schmid-Gadalbert (ed.), Dieth-Schreibung. Aarau: Sauerländer.

Dik, Simon C. (1997a). The Theory of Functional Grammar, Part 1: The Structure of the Clause. Berlin: Mouton de Gruyter.

- $(1997 b)$. The Theory of Functional Grammar, Part 2: Complex and Derived Constructions. Berlin: Mouton de Gruyter

- Hengeveld, Kees, Vester, Elseline, and Vet, Co (1990). 'The hierarchical structure of the clause and the typology of adverbial satellites', in Jan Nuyts, A. Machtelt Bolkestein, and Co Vet (eds), Layers and Levels of Representation in Language Theory. Amsterdam: Benjamins, 25-70.

Dimmendaal, Gerrit J. (1983a). The Turkana Language. Dordrecht: Foris.

- $(1983 b)$. 'Turkana as a verb-initial language', Journal of A frican Languages and Linguistics 5: 17-44.

- (to appear). 'Head marking, dependent marking and constituent order in the Nilotic area', in F. K. Erhard Voeltz (ed.), Studies in African Linguistic Typology. Amsterdam: Benjamins.

Dixon, Robert M.W. (1979). 'Ergativity', Language 55: 59-138.

- (1994). Ergativity. Cambridge: Cambridge University Press.

Doke, Clement M. (1992 [1927]). Text-book of Zulu Grammar. Cape Town: Maskew Miller Longman.

Dölling, Johannes (2003). 'Flexibility in adverbal modification: reinterpretation as contextual enrichment', in Lang et al. (2003: 511-52).

Dowty, David R. (1972). 'Temporally restrictive adjectives', in John Kimball (ed.), Syntax and Semantics, vol. i. New York: Seminar Press, 51-62.

- (1979). Word Meaning and Montague Grammar: The Semantics of Verbs and Times in Generative Semantics and in Montague's PTQ. Dordrecht: Reidel.

- (2003). 'The dual analysis of adjuncts/complements in Categorial Grammar', in Lang et al. (2003: 33-66).

Dürscheid, Christa (2002). " "Polemik satt und Wahlkampf pur": Das postnominale Adjektiv im Deutschen', Zeitschrift für Sprachwissenschaft 21: 57-81.

Duthie, Alan S. (1996). Introducing Ewe Linguistic Patterns. Accra: Ghana Universities Press.

Eckardt, Regine (1997). Events, Adverbs and Other Things. Ph.D. dissertation, University of Stuttgart.

Eisenberg, Peter (2002). 'Morphologie und Distribution: Zur Morphosyntax von Adjektiv und Adverb im Deutschen', in Friederike Schmöe (ed.), Das Adverb: Zentrum und Peripherie einer Wortklasse. Vienna: Praesens, 61-76.

Enfield, N. J. (2002a). 'Cultural logic and syntactic productivity: associated posture constructions in Lao', in N. J. Enfield (ed.), Ethnosyntax: Explorations in Culture and Grammar. Oxford: Oxford University Press, 231-58.

- (2002b). 'Semantics and combinatorics of "sit", "stand", and "lie" in Lao', in John Newman (ed.), The Linguistics of Sitting, Standing, and Lying. Amsterdam: Benjamins, 25-41. 
Enfield, N. J. (2003). Linguistic Epidemiology: Semantics and Grammar of Language Contact in Mainland Southeast Asia. London: Routledge Curzon.

- (2004). 'Adjectives in Lao', in Robert M. W. Dixon and Alexandra Y. Aikhenvald (eds), Adjective Classes: A Cross-Linguistic Typology, Oxford: Oxford University Press. 323-47.

- (to appear). 'Multi-verb sequences in Lao', in Anthony V. N. Diller and Jerold A. Edmondson (eds), The Tai-Kadai Languages. London: Routledge Curzon.

Enukašvili, Ruben (1977). 'Ṕrediḳațuli gasazyvrebis saḳitxi 3vel Kartulši', 3veli Kartuli Enis Katedris Šromebi 20: 151-64.

Ernst, Thomas (1984). Towards an Integrated Theory of Adverb Positions. Bloomington: Indiana University Linguistics Club.

- $(2000 a)$. 'Semantic features and the distribution of adverbs', in FabriciusHansen et al. (2000: 79-97).

- (2000b). 'Manners and events', in Tenny and Pustejovsky (2000: 335-58).

Essegbey, James (1999). Inherent Complement Verbs Revisited: Towards an Understanding of Argument Structure in Ewe. Ph.D. dissertation, Leiden University.

Evans, Nicholas D. (1995). A Grammar of Kayardild, with Historical-Comparative Notes on Tangkic. Berlin: Mouton de Gruyter.

Fabricius-Hansen, Cathrine, Lang, Ewald, and Maienborn, Claudia (eds) (2000). Approaching the Grammar of Adjuncts. Berlin: ZAS Papers in Linguistics 17.

Fanselow, Gisbert (2001). 'Features, theta-roles, and free constituent order', Linguistic Inquiry 32: 405-37.

Ferguson, Charles A. (1959). 'Diglossia', Word 15: 325-40.

Filipenko, Marina V. (2000). 'Adverbials with floating and fixed semantic scope', in Fabricius-Hansen et al. (2000: 99-106).

Fillmore, Charles J. (1988). 'The mechanisms of Construction Grammar', Berkeley Linguistic Society 14: 35-55.

Fintel, Kai von (1994). Restrictions on Quantifier Domains. Ph.D. dissertation, MIT. Fischer, Ludwig (1960). Luzerndeutsche Grammatik und Wegweiser zur guten Mundart. Zürich: Guggenbühl \& Huber.

Fleck, David (2003). A Grammar of Matses. Ph.D. dissertation, Rice University. Fortune, George (1955). An Analytical Grammar of Shona. London : Longmans Green. - (1984). Shona Grammatical Constructions, part ii. Harare: Mercury.

Fox, Danny (2000). Economy and Semantic Interpretation. Cambridge, Mass.: MIT Press. Frey, Werner (2000). 'Syntactic requirements on adjuncts', in Fabricius-Hansen et al. (2000: 107-134).

- and Pittner, Karin (1998). 'Zur Positionierung von Adverbialen im deutschen Mittelfeld', Linguistische Berichte 176: 489-534.

Fuchs, Gabriela (1993). 'Das prädikative Adjektiv und Partizip im Walliserdeutschen', in Helen Christen (ed.), Variationslinguistik und Dialektologie. Ergebnisse aus studienabschliessenden Arbeiten an der Universität Freiburg/Schweiz. Freiburg/ Schweiz: Germanistica Friburgensia 15, 65-79.

Gerber, Gustav (1871). Die Sprache als Kunst. Bromberg: Mittler'sche Buchhandlung. 
Geuder, Wilhem (2000). Oriented Adverbs: Issues in the Lexical Semantics of Event Adverbs. Ph.D. dissertation, Universität Konstanz.

Gigineišvili, Ivane, Topuria, Varlam, and Kavtaraze, Ivane (1961). Kartuli dialekțologia I: Kartuli enis kilota mokle ganxilva. Țeksțebi. Leksikoni/Gruzinskaja dialektologija I: Kratkij obzor dialektov gruzinskogo jazyka, Teksty. Slovar' (=Axali Kartuli Enis Katedris Šromebi 3). Tbilisi TU gam-ba.

Tlonți, Aleksandre (1955). 'Pilologiuri narḳvevebi. 2. Ațribuțiviani šemasmeneli Kartulši', Staliniris [Cxinvalis] Pedagogiuri Instițutis Šromebi 2: 254-8 (=Aleksandre Tlonți (1980), Pilologis čanaçerebi. Tbilisi: Sabçota Sakartvelo, 138-43).

- (1978). Kartuli çinadadeba. Savaržišo masala sințaksši. Tbilisi: Ganatleba.

Goddard, Cliff (1985). A Grammar of Yankunytjatjara. Alice Springs: Institute for Aboriginal Development.

- (1996). Pitjantjatjara/Yankunytjatjara to English Dictionary. Alice Springs: Institute for Aboriginal Development.

Goldberg, Adele E. (1995). Constructions: A Construction Grammar Approach to Argument Structure. Chicago: University of Chicago Press.

Green, Georgia (1970). 'How abstract is surface structure?'. Chicago Linguistics Society. Chicago: Chicago Linguistics Society, 270-81.

- (1973). 'A syntactic syncretism in English and French', in Bray B. Kachru et al. (eds), Issues in Linguistics: Papers in Honor of Henry and Renee Kahane. Urbana: University of Illinois Press, 257-78.

Green, Tom (1987). 'The Semantics of Temporal Clitics in Warlpiri'. MS, University of Sydney/MIT.

Güldemann, Tom (1996). Verbalmorphologie und Nebenprädikationen im Bantu. Eine Studie zur funktional motivierten Genese eines konjugationalen Subsystems. Bochum: Universitätsverlag Dr. N. Brockmeyer.

—- 1997 a). Prosodische Markierung als sprachliche Strategie zur Hierarchisierung verknüpfter Prädikationen am Beispiel des Shona. Leipzig: Institut für Afrikanistik, Universität Leipzig.

- $(1997 b)$. 'Prosodic subordination as a strategy for complex sentence construction in Shona: Bantu moods revisited', in Robert K. Herbert (ed.), African Linguistics at the Crossroads: Papers from Kwaluseni. Cologne: Rüdiger Köppe, 75-98.

- (1998). 'The relation between imperfective and simultaneous taxis in Bantu: late stages of grammaticalization', in Ines Fiedler, Catherine Griefenow-Mewis, and Brigitte Reineke (eds), Afrikanische Sprachen im Brennpunkt der Forschung. Linguistische Beiträge zum 12. Afrikanistentag Berlin, 3.-6. Oktober 1996. Cologne: Rüdiger Köppe, 157-77.

Gussenhoven, Carlos (1992). 'Sentence accents and argument structure', in Iggy M. Roca (ed.), Thematic Structure: Its Role in Grammar. Berlin: Foris, 79-105. Haider, Hubert (2001). 'Adverb placement: convergence of structure and licensing', Linguistics in Potsdam 6: 50-77.

Haiman, John (1983). 'On some origins of switch reference marking', in Haiman and Munro (1983: 105-28). 
Haiman, John and Munro, Pamela (eds) (1983). Switch-Reference and Universal Grammar. Amsterdam: Benjamins.

Hale, Kenneth (1976). 'The adjoined relative clause in Australia', in Robert M. W. Dixon (ed.), Grammatical Categories in Australian Languages. Canberra: Australian Institute of Aboriginal Studies, 78-105.

- (1981). 'Preliminary remarks on the grammar of part-whole relations in Warlpiri', in Jim Hollyman and Andrew Pawley (eds), Studies in Pacific Languages and Cultures: In Honour of Bruce Biggs. Auckland: Linguistics Society of New Zealand, 333-44.

- (1982). 'Some essential features of Warlpiri verbal clauses', in Swartz (1982: 217-315).

- (1983). 'Warlpiri and the grammar of non-configurational languages', Natural Language and Linguistic Theory 1: 5-47.

- (1994). 'Core structures and adjuncts in Walpiri syntax', in Norbert Corver and Henk van Riemsdijk (eds), Studies on Scrambling: Movement and Non-movement Approaches to Free Word-Order Phenomena. Berlin: Mouton de Gruyter, 185-219. - Laughren, Mary, and Simpson, Jane (1995). 'Warlpiri syntax', in Joachim Jacobs, Arnim von Stechow, Wolfgang Sternefeld, and Theo Vennemann (eds), Syntax: An International Handbook of Contemporary Research, vol. ii (Berlin: de Gruyter), 1430-51.

and Keyser, Jay (2001). The Basic Elements of Argument Structure. Cambridge, Mass.: MIT.

Halliday, Michael A. K. (1967). 'Notes on transitivity and theme in English, Part 1', Journal of Linguistics 3: 37-81.

Harada, Shin-Ichi (1975). 'The functional uniqueness principle', Attempts in Linguistics and Literature 2: 17-24.

Harvey, Mark (2002). A Grammar of Gaagudju. Berlin: Mouton de Gruyter.

Haspelmath, Martin (1994). 'Passive participles across languages', in Barbara Fox and

Paul J. Hopper (eds), Voice: Form and Function. Amsterdam: Benjamins, 151-78.

- (1995). 'The converb as a crosslinguistically valid category', in Haspelmath and König (1995: 1-56).

- (2003). 'The geometry of grammatical meaning: semantic maps and crosslinguistic comparison', in Michael Tomasello (ed.), The New Psychology of Language: Cognitive and Functional Approaches to Language Structure, vol. ii. Mahwah, NJ: Erlbaum, 211-42.

- and Buchholz, Oda (1998). 'Equative and similative constructions in the languages of Europe', in van der Auwera (1998: 277-334).

— and König, Ekkehard (eds) (1995). Converbs in Crosslinguistic Perspective: Structure and Meaning of Adverbial Verb Forms. Berlin: de Gruyter.

Hayward, Richard J. (ed.) (1990). Omotic Language Studies. London: School of Oriental and African Studies.

Heath, Jeffrey (1984). Functional Grammar of Nunggubuyu. Canberra: Australian Institute of Aboriginal Studies. 
Heim, Irene (1982). The Semantics of Definite and Indefinite Noun Phrases. Ph.D. dissertation, University of Massachusetts.

Helbig, Gerhard, and Buscha, Joachim (1994). Deutsche Grammatik. Ein Handbuch für den Ausländerunterricht, 16th edn. Berlin: Langenscheidt.

Hengeveld, Kees (1992a). Nonverbal Predication: Theory, Typology, Diachrony. Berlin: Mouton de Gruyter.

- $1992 b)$. 'Parts of speech', in Michael Fortescue, Peter Harder, and Lars Kristoffersen (eds), Layered Structure and Reference in a Functional Perspective: Papers from the Functional Grammar Conference in Copenhagen 1990. Amsterdam: Benjamins, 29-55.

Henzen, Walter (1927). Die deutsche Freiburger Mundart im Sense- und südöstlichen Seebezirk. Frauenfeld: Huber.

Herburger, Elena (2000). What Counts: Focus and Quantification. Cambridge, Mass.: MIT Press.

Higginbotham, James, Pianesi, Fabio, and Varzi, Achille C. (eds) (200o). Speaking of Events. Oxford: Oxford University Press.

Himmelmann, Nikolaus P. (1997). Deiktikon, Artikel, Nominalphrase. Zur Emergenz syntaktischer Struktur. Tübingen: Niemeyer.

(to appear). 'Lexicalization and grammaticization: opposite or orthogonal?', in Björn Wiemer, Walter Bisang, and Nikolaus Himmelmann (eds), What Makes Grammaticalization. A Look from its Components and its Fringes. Berlin: Mouton de Gruyter. Hinton, Leanne, Nichols, Johanna, and Ohala, John (eds) (1994). Sound Symbolism. Cambridge: Cambridge University Press.

Hotzenköcherle, Rudolf (1934). Die Mundart von Mutten. Laut- und Flexionslehre. Frauenfeld: Huber.

- (1961). 'Die Raumstruktur des Schweizerdeutschen', Zeitschrift für Mundartforschung 3: 207-27.

Hudson, Joyce (1978). The Core of Walmatjarri Grammar. Canberra: Australian Institute of Aboriginal Studies.

Hyman, Larry M., and Watters, John R. (1984). 'Auxiliary focus', Studies in African Linguistics 15: 233-73.

Idiotikon: Schweizerisches Idiotikon. Wörterbuch der schweizerdeutschen Sprache ed. Friedrich Staub and Ludwig Tobler. Frauenfeld: Huber, vol. i (1881).

Imnaišvili, Ivane (1948). 'Šedgenili šemasmeneli Kartulši'/Sostavnoe skazuemoe v gruzinskom jazyke (Résumé 214), Puškinis saxelobis Saxelmçipo Pिedagogiuri Institutis Šromebi 5: 187-216.

_- (1957). Saxelta bruneba da brunvata punkciebi 3vel Kartulši (=3veli Kartuli Enis Katedris Šromebi 4). Tbilisi: Tbilisis universțțis gamomcemloba.

Imnaišvili, Vaxțang (1997). 'Zu einer Art des "einfachen Objekts". im Georgischen', Georgica 20: 83-8.

Jackendoff, Ray S. (1972). Semantic Interpretation in Generative Grammar. Cambridge, Mass.: MIT Press.

Jacobs, Joachim, (1997). 'I-Topikalisierung', Linguistische Berichte 168: 91-133. 
Jacobs, Joachim, von Stechow, Arnim, Sternefeld, Wolfgang and Vennemann, Theo (eds)

(1995). Syntax: An International Handbook of Contemporary Research. Berlin: de Gruyter. Jaggar, Philip (1992). An Advanced Hausa Reader with Grammatical Notes and Exercises. London: School of Oriental and African Studies.

Jakobson, Roman (1936). 'Beitrag zur allgemeinen Kasuslehre. Gesamtbedeutungen der russischen Kasus', in Roman Jakobson, Selected Writings, vol. ii. The Hague: Mouton de Gruyter, 23-71.

- (1971 [1957]). 'Shifters, verbal categories, and the Russian verb', in Roman Jakobson, Selected Writings vol. ii. The Hague: Mouton de Gruyter, 130-47.

Janda, Laura A. (1993). A Geography of Case Semantics: The Czech Dative and the Russian Instrumental. Berlin: Mouton de Gruyter.

Jespersen, Otto (1965). A Modern English Grammar on Historical Principles, part iii: Syntax, and vol. London: Allen \& Unwin.

Johanson, Lars (1995). 'On Turkic converb clauses', in Haspelmath and König (1995: 313-47).

Johnston, Michael (1995). 'When-clauses, adverbs of quantification, and focus', in Susanne Preuss, Raul Aranovich, William Byrne, and Martha Senturia (eds), Proceedings of the 13th West Coast Conference in Formal Linguistics. Cambridge: Cambridge University Press, 549-64.

Katz, Graham (1993). The Semantics of Free Adjuncts: Deriving the Weak/Strong Distinction. Cambridge Mass.: MIT Working Papers in Linguistics 20.

- (2000). 'Anti neo-Davidsonianism: against a Davidsonian semantics for state sentences', in Tenny and Pustejovsky (2000: 393-416).

Kay, Paul, and Fillmore, Charles J. (1999). 'Grammatical constructions and linguistic generalizations: the what's $X$ doing $Y$ ? construction', Language 75: 1-33.

Keenan, Edward L., and Comrie, Bernard (1977). 'Noun phrase accessibility and universal grammar', Linguistic Inquiry 8: 63-99.

Kilham, Christine, Pamulkan, Mabel, Pootchemunka, Jennifer, and Wolmby, Topsy (1986). Dictionary and Source Book of the Wik-Munkan Language. Darwin: Summer Institute of Linguistics.

Kiiziria, Anțon (1977). 'Gavrcobili šemasmeneli Kartvelur enebši', Sakartvelos SSR Mecnierebata Akademiis Enatmecnierebis Instituți, Tezisebi 33: 9-11.

Klimov, Georgij (1974). 'On the character of active languages', Linguistics 131: 11-23. Kniffka, Gabriele (1996). NP-Aufspaltung im Deutschen. Hürth: Gabel.

Kofod, Frances M. (n.d.). 'Introduction to Kija grammar'. MS.

Koizumi, Masatoshi (1994). 'Secondary predicates', Journal of East Asian Linguistics 3: 25-59.

König, Ekkehard; and Van der Auwera, Johan (1990). 'Adverbial participles, gerunds and absolute constructions in the languages of Europe', in Johannes Bechert, Giuliano Bernini, and Claude Buridant (eds), Toward a Typology of European Languages. Berlin: Mouton de Gruyter, 337-55.

Koster, Jan, and Zwart, Jan-Wouter (2000). 'Transitive expletive constructions and the object shift parameter'. MS, University of Groningen. 
Kratzer, Angelika (1995). 'Stage-level and individual-level predicates', in Carlson and Pelletier (1995: 125-75).

Kroeger, Paul R. (1993). 'Another look at subjecthood in Tagalog', Philippine Journal of Linguistics 24(2): 1-15.

Kuno, Susumu, and Takami, Ken-Ichi (1993). Grammar and Discourse Principles: Functional Syntax and GB Theory. Chicago: University of Chicago Press.

Kutsch Lojenga, Constance (1994). Ngiti: A Central-Sudanic Language of Zaire. Cologne: Rüdiger Köppe.

Kutscher, Silvia (2001). Nomen und nominales Syntagma im Lasischen. Eine deskriptive Analyse des Dialekts von Ardeşen. Munich: Lincom Europa.

- and Genç, Nuran Sevim (1998). Ardeşen narrates-Ardeşeni na isinapinenpe. A Collection of Laz Spoken Texts with Glosses and Translations into English, German and Turkish. Munich: Lincom Europa.

Mattissen, Johanna, and Wodarg, Anke (eds) (1995). Das Mut'afi-Lazische. Cologne: Department of Linguistics, University of Cologne.

Ḳvaçanțiraze, Tamaz (1978). Msgavsebiti šedareba Kartulši. Tbilisi: Tbilisis universțțis gamomcemloba.

Ḳvaçaze, Leo (1957). 'Mimyeobisa da saxelis zogierti pormis sințaksuri ḳvalipiḳaciisatvis', Komunisturi Ayzrdisatvis 12: 27-36.

- (1996). Tanamedrove Kartuli enis sințaksi. Meotxe ševsebuli gamocema. Tbilisi: Rubikoni.

- (1999). 'Predikațuli gansazyvreba 3vel Kartulši’, Enatmecnierebis Saḳitxebi 1999(4): 31-40.

- (2000a). 'Predikațuli gansazyvreba Kartuli enis dialektebšì', Enatmecnierebis Sakitxebi 2000(3): 3-9.

- (2000b). 'Predikațuli gansazyvreba Svanurši', Sulxan-Saba Orbelianis saxelobis Tbilisis Saxelmçipo Pُ edagogiuri Universițțis Kartuli Enis Katedris Šromebi 5: 5-12.

Lamberti, Marcello, and Sottile, Roberto (1997). The Wolaitta Language. Cologne: Rüdiger Köppe.

Landman, Fred (2001). Events and Plurality. Dordrecht: Kluwer.

Lang, Ewald, Maienborn, Claudia, and Fabricius-Hansen, Cathrine (eds) (2003). Modifying Adjuncts. Berlin: de Gruyter.

Larson, Richard K. (1988). 'On the double object construction', Linguistic Inquiry 19: $335-91$.

- (1991). 'Some issues in verb serialization', in Claire Lefebvre (ed.), Serial Verbs: Grammatical, Comparative and Cognitive Approaches. Amsterdam: Benjamins, 185-210.

Laughren, Mary (1992). 'Secondary predication as a diagnostic of underlying structure in Pama-Nyungan languages', in Iggy Roca (ed.), Thematic Structure: Its Role in Grammar. Berlin: Mouton de Gruyter, 199-246.

-(2002). 'Syntactic constraints in a free word order language', in Mengistu Amberber and Peter Collins (eds), Language Universals and Variation. Westport, Conn.: Ablex Greenwood, 83-130. 
Laughren, Mary (in press). 'Some Warlpiri non-finite clauses reviewed', in Rachel Nordlinger (ed.), Australian Journal of Linguistics, Special Issue.

Lazoğlu, Fahri, and Feurstein, Wolfgang (1984). Lazuri Alfabe. Lazca Alfabe. Entwurf eines lazischen Alphabetes. Parpali 1. Lazuri Carelepe. Laz dili ve kültürü yayınlarn. Progrom.

Lechner, Winfried (2001). 'Phrase structure paradoxes, movement and ellipsis'. MS, University of Tübingen.

Legendre, Géraldine (1997). 'Secondary predication and functional projections in French', Natural Language and Linguistic Theory 15(1): 43-87.

Lehmann, Christian (1988). 'Towards a typology of clause linkage', in John Haiman and Sandra A. Thompson (eds), Clause Combining in Grammar and Discourse. Amsterdam: Benjamins, 181-225.

Lehmann, Thomas (1993). A Grammar of Modern Tamil Pondicherry: Pondicherry Institute of Linguistics.

Lewis, David (1975). 'Adverbs of quantification', in Edward Keenan (ed.), Formal Semantics. Cambridge: Cambridge University Press, 3-15.

Lewis, Marshall (1985). Ewe Relativization, NP Accessibility and Universal Grammar. Bloomington: Department of Linguistics, Indiana University.

Li, Charles N., and Thompson, Sandra A. (1981). Mandarin Chinese: A Functional Reference Grammar. Berkeley: University of California Press.

Loos, Eugene E. (1999). 'Pano', in Robert M. W. Dixon and Alexandra Y. Aikhenvald (eds), The Amazonian Languages. Cambridge: Cambridge University Press, 227-50.

Lübker, Friedrich (1837). Grammatische Studien. Studien zur Syntax des Adjectivums und Adverbiums in den alten Sprachen. Parchim und Ludwigslust: Hinstorff sche Hofbuchhandlung.

McConnell-Ginet, Sally (1982). 'Adverbs and logical form', Language 58: 144-84.

McGregor, William B. (1989). 'Phrase fracturing in Gooniyandi', in László Marácz and Pieter Muysken (eds), Configurationality: The Typology of Asymmetries. Dordrecht: Foris, 207-22.

- (1990). A Functional Grammar of Gooniyandi. Amsterdam: Benjamins.

(1992a). 'The noun phrase in (some) Australian languages: a reply to Mark Harvey', Australian Journal of Linguistics 12: 315-19.

- $(1992 b)$. 'The semantics of ergative marking in Gooniyandi', Linguistics 30: 275-318.

- (1997a). 'Functions of noun phrase discontinuity in Gooniyandi', Functions of Language 4: 83-114.

- $(1997 b)$. 'Indefinite and comparative determiners in Australian languages". Paper presented at the Second International Workshop on Australian Linguistics, University of Melbourne, December 1997.

- (1997c). Semiotic Grammar. Oxford: Clarendon Press.

-(1998a). 'Numeral and Quantifying Words in Australian Languages'. Paper presented to Institut für Sprachwissenschaft and Institut für Didaktik der Naturwissenschaft, Universität Salzburg. 
(1998b). 'Optional ergative marking in Gooniyandi revisited: implications to the theory of marking', Leuvense Bijdragen 87: 491-534.

McKay, Graham (2000). 'Ndjébbana', in Robert M. W. Dixon and Barry Blake (eds), The Handbook of Australian Languages, vol. 5. Melbourne: Oxford University Press Australia, 154-354.

McNulty, Elaine (1988). The Syntax of Adjunct Predicates. Ph.D. dissertation, University of Connecticut.

Maienborn, Claudia (2000). 'Modification and underspecification: a free variable account of locative modifiers', in Fabricius-Hansen et al. (2000: 153-76).

- (2001). 'On the position and interpretation of locative modifiers', Natural Language Semantics 9: 191-240.

Malchukov, Andrej (1996). 'Internal relative clauses in Tungusic languages in a synchronic and diachronic perspective', Sprachtypologie und Universalienforschung 4: 358-82.

Manser, Joe (2001). Innerrhoder Dialekt. Mundartwörter und Redewendungen aus Appenzell Innerrhoden. Appenzell: Appenzeller Volksfreund.

Maslov, Jurij S. (1988). 'Resultative, perfect, and aspect', in Vladimir P. Nedjalkov (ed.), Typology of Resultative Constructions. Amsterdam: Benjamins, 257-67.

Mattissen, Johanna (1995). 'Verbmorphologie', in Kutscher et al. (1995: 45-82).

Menge, Hermann (2000). Lehrbuch der lateinischen Syntax und Semantik. Completely new edition by Thorsten Burkard. Darmstadt: Wissenschaftliche Buchgesellschaft.

Merkle, Ludwig (1975). Bairische Grammatik. Munich: Heimeran.

Merlan, Francesca (1982). Mangarayi. Amsterdam: North-Holland.

Meeussen, Achille E. (1967). 'Bantu grammatical reconstructions', Africana Linguistica 3: 79-121.

Milsark, Gary L. (1974). Existential Sentences in English. Ph.D. dissertation, MIT.

Moulton, William G. (1941). Swiss German Dialect and Romance Patois. Ph.D. dissertation, Yale University.

Müller, Stefan (2002). Complex Predicates: Verbal Complexes, Resultative Constructions, and Particle Verbs in German. Stanford, Calif.: CSLI.

Müller-Bardey, Thomas (1990). 'Koprädikation als grundlegende syntaktische Operation', in Hansjakob Seiler with Elfie Konrad and Birgit Schwarze (eds), Internationales interdisziplinäres Kolloquium 'Sprache und Denken: Variation und Invarianz in Linguistik und Nachbardisziplinen', Lenzburg/Schweiz, May 1989. Cologne: Arbeiten des Kölner Universalien-Projekts (akup) 81, 1-20.

Nakajima, Heizo (1990). 'Secondary predication', Linguistic Review 7(3): 275-309. Napoli, Donna Jo (1975). 'A global agreement phenomenon', Linguistic Inquiry 3: 413-35.

- (1989). Predication Theory: A Case Study for Indexing Theory. Cambridge: Cambridge University Press.

Nash, David (1982). 'Warlpiri preverbs and verb roots', in Swartz (1982: 165-216). - (1986). Topics in Warlpiri Grammar. New York: Garland.

Nedjalkov, Igor V. (1997). Evenki. London: Routledge. 
Nedjalkov, Vladimir P. (1995). 'Some typological parameters of converbs', in Haspelmath and König (1995: 97-136).

Neeleman, Ad (1994). Complex Predicates. Utrecht: Led.

Nekes, Herman, and Worms, Ernest A. (1953). Australian Languages. Fribourg: Anthropos Institut.

Newman, Paul (2000). The Hausa Language: An Encyclopedic Reference Grammar. New Haven, Conn.: Yale University Press.

Nichols, Joanna (1978a). 'Secondary predicates', Berkeley Linguistics Society 4:

$114-27$.

- (1978b). 'Double dependency?', Chicago Linguistics Society 14: 326-39.

(1981). Predicate Nominals: A Partial Surface Syntax of Russian. Berkeley:

University of California Press.

- (1982). 'Prominence, cohesion, and control: object-controlled predicate nominals in Russian', in Paul Hopper and Sandra A. Thompson (eds), Studies in Transitivity. New York: Academic Press, 317-50.

- (1983). 'Switch reference in the Northeast Caucasus', in Haiman and Munro (1983: 245-65).

- (1986). 'Head-marking and dependent-marking grammar', Language 62: 56-119.

Ogawa, Yoshiki (2001). 'The stage/individual distinction and (in)alienable possession', Language 77(1): 1-25.

Paul, Hermann (1919). Deutsche Grammatik, vol. iii. Halle (Saale): VEB Max Niemeyer.

- (1998). Mittelhochdeutsche Grammatik. 24th edn. Tübingen: Niemeyer.

Pianesi, Fabio, and Varzi, Achille C. (2000). 'Events and event talk: an introduction', in Higginbotham et al. (2000: 3-47).

Pinkster, Harm (1988). Lateinische Syntax und Semantik. Tübingen: Francke.

Pittner, Karin (1999). Adverbiale im Deutschen. Untersuchungen zu ihrer Stellung und Interpretation. Tübingen: Stauffenburg.

Plank, Frans (1985). 'Prädikativ und Koprädikativ', Zeitschrift für Germanistische Linguistik 13(2): 154-85.

Platt, John 'T., and Platt, Heidi K. (1972). 'Orientation of manner adverbials', Papers in Linguistics: 227-49.

[Q̇ipšize, Ioseb] (1914). I. Kipšidze: Grammatika mingrel'skago (iverskago) jazyka s" chrestomatieju i slovarem" ( $=$ Materialy po jafetičeskomu jazykoznaniju 7). Sankt Peterburg: Tipografija Imperatorskoj Akademii Nauk".

Quirk, Randolph, Greenbaum, Sidney, Leech, Geoffrey, and Svartvik, Jan (1985). A Comprehensive Grammar of the English Language. London: Longman.

Rapoport, Tova R. (1991). 'Adjunct predicate licensing and D-structure', in Susan Rothstein (ed.), Perspectives of Phrase Structure: Heads and Licensing. San Diego, Calif.: Academic Press, 159-87.

- (1993). 'Verbs in depictives and resultatives', in James Pustejovsky (ed.), Semantics and the Lexicon. Dordrecht: Kluwer, 163-84.

- (1999). 'Structure, aspect, and the predicate', Language 75: 653-77. 
Reinhart, Tanya (1995). 'Interface economy and markedness', in Chris Wilder, Hans-Martin Gärtner, and Manfred Bierwisch (eds), The Role of Economy Principles in Linguistic Theory. Berlin: Akademie, 146-69.

Roberts, Ian (1988). 'Predicative APs', Linguistic Inquiry 19(4): 703-10.

Rooth, Mats (1995). 'Indefinites, adverbs of quantification, and focus semantics', in Carlson and Pelletier (1995: 265-99).

Rosen, Georg (1844). Über die Sprache der Lazen. Lemgo, Detmold: Meyersche Hofbuchhandlung.

Rothstein, Susan D. (1985). The Syntactic Forms of Predication. Bloomington: Indiana University Linguistics Club.

- (2000). 'Secondary predication and aspectual structure', in Fabricius-Hansen et al. (2000: 241-64).

-(2001). Predicates and their Subjects. Dordrecht: Kluwer Academic.

Rottland, Franz (1982). Die südnilotischen Sprachen. Beschreibung, Vergleichung und Rekonstruktion. Berlin: Reimer.

SADS: Syntaktischer Atlas der Deutschen Schweiz (ongoing project). Saltarelli, Mario (1988). Basque. London: Routledge. Šanize, Akaki, and Topuria, Varlam (eds) (1939). Svanuri prozauli tekstebi I. Balszemouri ǩilo. Țeksțebi šekrribes A, Šanizem da V. Topuriam (Masalebi Kartvelur enata šesçavlisatvis. I.) (SSRK Mecnierebata Aḳademiis Sakartvelos Piliali. ENIMḲI.) Tbilisi: SSRK Mecnierebata Akademiis Sakartvelos Pilialis gamomcemloba.

and Kaldani, Maksime (eds.) (1978). Svanuri enis krestomatia. țeksțebi šekribes A. Šanizem, M. Kaldanma da Z. Çumburizem (=zveli Kartuli enis ḳatedris šromebi 21). Tbilisi: Tbilisis universțțtis gamomcemloba.

Sapir, David J. (1977). 'The anatomy of metaphor', in David J. Sapir and Jon C. Crooker (eds), The Social Use of Metaphor. Philadelphia: University of Pennsylvania Press, 3-32. Schein, Barry (1995). 'Small clauses and predication', in Anna Cardinaletti and Maria Teresa Guasti (eds), Small Clauses. New York: Academic Press, 49-76.

Schroeder, Christoph (2003). Depiktive im Sprachvergleich Deutsch-Türkisch. Eine kontrastiv-typlogische Analyse. Habilitationsschrift, Universität Osnabrück.

Schultze-Berndt, Eva (2000). Simple and Complex Verbs in Jaminjung: A Study of Event Categorisation in an Australian Language. Ph.D. dissertation, Catholic University of Nijmegen.

- (2001). 'The cognitive basis of allative marking of secondary predicates: evidence from Australian languages'. Paper presented at the International Cognitive Linguistics Conference, Santa Barbara, Calif., 24 July 2001.

- (2002). 'Grammaticalized restrictive clitics on adverbials and secondary predicates: evidence from Australian languages', Australian Journal of Linguistics 22(2): 231-64.

- - and Dawuda, Carmen (2001). 'German depictive secondary predicates in a typological perspective'. MS, Ruhr-Universität Bochum.

— and Himmelmann, Nikolaus P. (2004). 'Depictive secondary predicates in crosslinguistic perspective', Linguistic Typology 8(1): 59-131. 
SDS: Sprachatlas der deutschen Schweiz (1975). Band iii, Formengeographie, bearbeitet von Doris Handschuh, Rudolf Hotzenköcherle, Rudolf Trüb u.a., Bern.

Sicard, Harald von (1965). Ngano dze Cikaranga (Karangamärchen). Uppsala: Institutionen för Allmän och Jämförende Etnografi vid Uppsala Universitet.

Sievers, Eduard (1892). Tatian. Lateinisch und altdeutsch mit ausführlichem Glossar, 2nd ed. Paderborn: Schöningh.

Simpson, Jane (1988). 'Case and complementiser suffixes in Warlpiri', in Austin (1988: 205-18).

- (1991). Warlpiri Morphosyntax: A Lexicalist Approach. Dordrecht: Kluwer.

and Bresnan, Joan (1983). 'Control and obviation in Warlpiri', Natural Language and Linguistic Theory 1: 49-64.

Soi Rawa (Guillermo Ramírez Guimaraes) (1995). Soi Rawa: joni benatian non moabo ipaoni. Programa de Formación de Maestros Bilingües de la Amazonía Peruana. Lima: Asociación Interétnica de Desarrollo de la Selva Peruana and Instituto Superior Pedagógico 'Loreto'.

Sonderegger, Stefan, and Gadmer, Thomas (1999). Appenzeller Sprachbuch. Der Appenzeller Dialekt in seiner Vielfalt. Appenzell \& Herisau: Erziehungsdirektionen AR und AI.

Spagnolo, L.M. (1933). Bari Grammar. Verona: Missioni Africane.

- (1960). Bari English Italian Dictionary. Verona: Missioni Africane.

Sparing-Chávez, Margarethe (1998). 'Interclausal reference in Amahuaca', in

Desmond C. Derbyshire and Geoffrey K. Pullum (eds), Handbook of Amazonian Languages, vol. iv. Berlin: Mouton de Gruyter, 443-85.

Steube, Anita (1994). 'Syntaktische und semantische Eigenschaften selkundärer Prädikate', in Anita Steube and Gerhild Zybatow (eds), Zur Satzwertigkeit von Infinitiven und Small Clauses. Tübingen: Niemeyer, 243-64.

Stowell, Timothy (1981). Origins of Phrase Structure. Ph.D. dissertation, MIT.

Stucki, Karl (1917). Die Mundart von Jaun im Kanton Freiburg. Lautlehre und Flexion. Frauenfeld: Huber.

Stump, Gregory T. (1985). The Semantic Variability of Absolute Constructions. Dordrecht: Reidel.

Swartz, Stephen M. (ed.) (1982). Papers in Warlpiri Grammar, in Memory of Lothar Jagst. Berrimah, NT: Summer Institute of Linguistics.

- (1991). Constraints on Zero Anaphora and Word Order in Warlpiri Narrative Text. Darwin, NT: Summer Institute of Linguistics.

Szadrowsky, Manfred (1936). 'Zur hochalemannischen Syntax IV', Beiträge zur Geschichte der Deutschen Sprache und Literatur 60: 445-58.

Takezawa, Koichi (1993). 'Secondary predication and locative/goal phrases', in Nobuko Hasegawa (ed.), Japanese Syntax in Comparative Grammar. Tokyo: Kurosio, 45-77. Tenny, Carol (2000). 'Core events and adverbial modification', in Tenny and Pustejovsky (2000: 285-334).

- and Pustejovsky, James (eds) (2000). Events as Grammatical Objects: The Converging Perspectives of Lexical Semantics and Syntax. Stanford Calif.: CSLI. 
Tobler, Titus (1837). Appenzellischer Sprachschatz. Zürich: Orell Füssli.

Toweett, Taaitta (1979). A Study of Kalenjin Linguistics. Nairobi: Kenya Literature Bureau. Uturgaize, Tedo (1960). Tušuri ḳilo (=3veli Kartuli Enis Katedris Šromebi 6). Tbilisi: Tbilisis universțțis gamomcemloba.

Valenzuela, Pilar M. (1997). 'Basic verb types and argument structures in ShipiboConibo'. MA thesis, University of Oregon.

- (1998). 'El morfema de ergatividad en el Shipibo-Conibo', in Luis Miranda and Amanda Orellana (eds), Actas del II Congreso Nacional de Investigaciones Lingüistico-Filológicas. Lima, Peru: Universidad Ricardo Palma, 217-45.

- (1999). 'Adverbials, transitivity and switch-reference in Shipibo-Konibo (Panoan)', in Sabrina J. Billings, John P. Boyle, and Aaron M. Griffith (eds), Chicago Linguistic Society 35: Theory and Linguistic Diversity. Chicago: Chicago Linguistic Society, 355-71.

- (2002). 'Causativization and transitivity in Shipibo-Konibo', in Masayoshi Shibatani (ed.), The Grammar of Causation and Interpersonal Manipulation. Amsterdam: Benjamins, 417-83.

- (2003). Transitivity in Shipibo-Konibo Grammar. Ph.D. dissertation, University of Oregon.

Valiquette, Hilaire (1993). A Basic Kukatja to English Dictionary. Wirrimanu (Balgo): Luurnpa Catholic School.

Van der Auwera, Johan (ed.) (1998). Adverbial Constructions in the Languages of Europe. Berlin: Mouton de Gruyter.

— and Plungian, Vladimir (1998). 'Modality's semantic map', Linguistic Typology 2: 79-124.

Van Valin, Robert, and LaPolla, Randy J. (1997). Syntax: Structure, Meaning and Function. Cambridge: Cambridge University Press.

Vendler, Zeno (1967). 'Verbs and times', in Zeno Vendler, Linguistics in Philosophy. Ithaca, NY: Cornell University Press, 97-121.

Voeltz, F. K. Erhard, and Kilian-Hatz, Christa (eds) (2001). Ideophones. Amsterdam: Benjamins.

Vogel, Petra M. (1997). 'Unflektierte Adjektive im Deutschen. Zum Verhältnis von semantischer Struktur und syntaktischer Funktion und ein Vergleich mit flektierten Adjektiven', Sprachwissenschaft 22: 403-33.

Walch, Maria (forthcoming). 'Bsuffig mit einem gstohligen Auto fahren: Zur Morphosyntax des Partizips II in einem oberdeutschen Dialekt', in Marie Vachková (ed.), Festschrift für Alena Šimečková. Prague: Germanistica Pragensia.

Watkins, Mark H. (1937). A Grammar of Chichewa: A Bantu Language of British Central Africa. Philadelphia: Linguistic Society of America and University of Pennsylvania.

Westermann, Diedrich (1930). A Study of the Ewe Language. Oxford: Oxford University Press.

Wilkins, David P. (1988). 'Switch reference in Mparntwe Arrernte (Aranda): form, function, and problems of identity', in Austin (1988: 141-76). 
Wilkins, David P. (1989). Mparntwe Arrernte (Aranda): Studies in the Structure and

Semantics of Grammar. Ph.D. dissertation, Australian National University.

Wilkinson, Melanie (1991). Djambarrpuyngu: A Yolngu Variety of Northern Australia.

Ph.D. dissertation, University of Sydney.

Williams, Edwin (1980). 'Predication', Linguistic Inquiry 11: 203-38.

- (1983). 'Against small clauses', Linguistic Inquiry 14: 287-300.

Wilson, Stephen (1999). Coverbs and complex predicates in Wagiman. Stanford, Calif.: CSLI.

Winkler, Susanne (1997). Focus and Secondary Predication. Berlin: Mouton de Gruyter. Wipf, Elsa (1910). Die Mundart von Visperterminen im Wallis. Frauenfeld: Huber.

WÖB: Wörterbuch der bairischen Mundarten in Österreich. 1963-1999. Herausgegeben im Auftrag der Österreichischen Akademie der Wissenschaften, bearb. von Viktor Dollmayr und Eberhard Kranzmayer. Vienna. Bd. $i-$ iii.

Wodarg, Anke (1995). 'Textsammlung', in Kutscher et al. (1995: 113-32).

Wyner, Adam Z. (1994). Boolean Event Lattices and Thematic Roles in the Syntax and the Semantics of Adverbial Modification. Ph.D. dissertation, Cornell University.

Wyngaerd, Guido Vanden (2001). 'Measuring events', Language 77: 61-90

Xubua, Maḳar (1937). Megruli tekstebi/Megrel'skie teksty/Textes mégréliens (SSRK Mecnierebata Aḳademiis Sakartevelos Piliali, ENIMḲI). Tbilisi: SSRK MA Sakartvelos Pilialis gamomcemloba.

Yadav, Ramamatar (1996). A Reference Grammar of Maithili. Berlin: Mouton de Gruyter.

Yatsushiro, Kazuko (1999). Case Licensing and VP Structure. Ph.D. dissertation, University of Connecticut (distributed by MIT: Working Papers in Linguistics).

Zavala, Roberto (to appear). 'Serial verb constructions in Olutec', in Aikhenvald and Dixon (to appear).

Zehetner, Ludwig (1985). Das bairische Dialektbuch. Munich: Beck.

Zhang, Niina (2000). 'The structure of depictive and resultative constructions in Chinese', ZAS Papers in Linguistics 22: 191-221.

Zwicky, Arnold (1987). 'Constructions in monostratal syntax', Chicago Linguistic Society 23: $389-401$. 